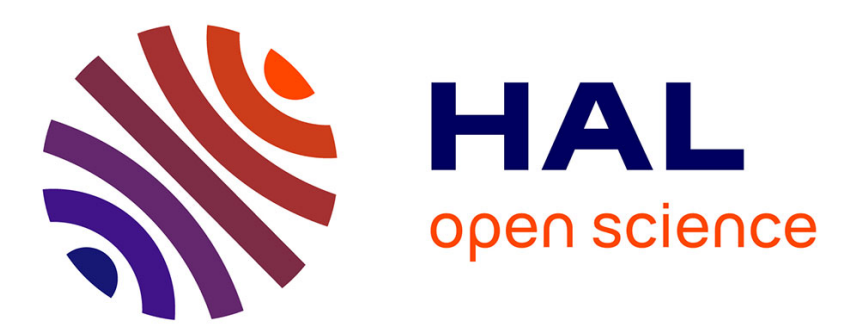

\title{
Variations in maize pollen emission and deposition in relation to microclimate
}

Nathalie Jarosz, Benjamin Loubet, Brigitte Durand, Xaxier Foueillassar, Laurent Huber

\section{- To cite this version:}

Nathalie Jarosz, Benjamin Loubet, Brigitte Durand, Xaxier Foueillassar, Laurent Huber. Variations in maize pollen emission and deposition in relation to microclimate. Environmental Science and Technology, 2005, 39, pp.4377-4384. 10.1021/es0494252 . hal-00351096

\section{HAL Id: hal-00351096 https://hal.science/hal-00351096}

Submitted on 8 Jan 2009

HAL is a multi-disciplinary open access archive for the deposit and dissemination of scientific research documents, whether they are published or not. The documents may come from teaching and research institutions in France or abroad, or from public or private research centers.
L'archive ouverte pluridisciplinaire HAL, est destinée au dépôt et à la diffusion de documents scientifiques de niveau recherche, publiés ou non, émanant des établissements d'enseignement et de recherche français ou étrangers, des laboratoires publics ou privés. 


\title{
Variations in maize pollen emission and deposition in relation to microclimate
}

\author{
Nathalie Jarosz ${ }^{1}$, Benjamin Loubet ${ }^{1}$, Brigitte Durand ${ }^{1}$, Xavier Foueillassar ${ }^{2}$ \& Laurent Huber $^{1}$ \\ ${ }^{1}$ INRA - EGC, 78850 Thiverval-Grignon, France \\ ${ }^{2}$ Arvalis, Insitut du végétal, 21 Chemin de Pau, 64121 Montardon, France
}

Environmental Science and Technology, 2005, 39, 4377-4384

\begin{abstract}
The co-existence of genetically modified (GM) crops with conventional crops has become a subject of debate and inquiry. Maize (Zea mays L.) is one of the most cultivated crop plants in the world and there is a need to assess the risks of cross-pollination. Concentration and deposition rate downwind from different-sized maize crops were measured during three flowering seasons, together with micrometeorological conditions in the surrounding environment. Pollen release started once the air vapour pressure deficit (VPD) increases above 0.2 to $0.5 \mathrm{kPa}$. Moreover, the dynamics of release was correlated with the dynamics of VPD surrounding the tassels. Horizontal deposition appeared to follow a power law over short distance downwind from the source, and the dispersal distance increased with the source canopy height, and the roughness length of the downwind canopy. This work also provides a data set containing both pollen measurements and contrasting weather conditions to validate dispersal models and further investigate maize pollen dispersal processes.
\end{abstract}

KEYWORDS: production, dispersion, atmospheric transport, deposition velocity, field experiment 


\section{Introduction}

For many years, plant breeders have been interested in pollen spread as it is related to the maintenance of seed purity. The introduction of genetically modified (GM) crops has increased the need to understand and model gene flow between crops, especially for maize (Zea mays L.) which is the second most commercialized GM crop in the world (1). Moreover, maize is primarily wind-pollinated and therefore is a pertinent plant "model” for studying the physical processes involved in the aerial motion of pollen.

Maize pollen dispersal studies often deal with effective dispersal experiments (2-5). Such studies can give direct estimates of out-crossing rates, but are of limited use as predictive tools because they are only valid for the meteorological conditions encountered during the experiments. With the recent progress in the physical modelling of pollen dispersal (6), a great range of weather conditions, plant (height) and pollen (size, weight) characteristics can be investigated. These models need however to be validated (7) which requires specific datasets with time averaging made over short periods. There is therefore a necessity for a better description of hourly patterns of pollen emission, airborne concentration and deposition rates, as a function of environmental variables, as well as plant functioning.

There are a few studies reporting maize pollen dispersal experiments with airborne concentration and deposition measurements $(8,9)$. However, they have been limited to short downwind distances (often less than $100 \mathrm{~m})(6,10,11)$. Direct measurement of pollen release rates is difficult and consequently the temporal pattern of emission is poorly known (12), except (8) who reported hourly patterns of maize pollen emission based on measurement of concentration above the source. On the contrary, daily maize pollen production has been estimated in several studies using different methods: tassel bags on plants grown in pots (13); passive samplers below the source and image analysis (14); as well as tassel bags and a continuous particle sampler above the source (8).

In this study, we report on the measurements of airborne concentration and deposition rate of maize pollen downwind from a small size plot in 2000 and 2001 and a large commercial field in 2002. Measurements were made up to $200 \mathrm{~m}$ downwind from the source in 2001 and $400 \mathrm{~m}$ in 2002. We compare pollen release rates inferred using a dispersal model with pollen production measured in the field and we examine the influence of environmental factors on pollen emission dynamics. We also discuss the influence of changes in aerodynamic roughness and maize canopy height on deposition rates. 


\section{Material and Methods}

Experimental sites. Three experiments were performed in France in different locations: Montargis (latitude $48^{\circ} 00^{\prime} \mathrm{N}$, longitude $2^{\circ} 44^{\prime} \mathrm{E}$, altitude $90 \mathrm{~m}$ ) in 2000; Grignon (latitude $48^{\circ} 51^{\prime} \mathrm{N}$, longitude $1^{\circ} 55^{\prime} \mathrm{E}$, altitude $=101 \mathrm{~m}$ ) in 2001 ; and Sore (latitude $44^{\circ} 19^{\prime} \mathrm{N}$; longitude $0^{\circ} 34^{\prime} \mathrm{W}$; altitude $71 \mathrm{~m}$ ) in 2002. The experiment at Montargis has already been reported (8) and will not be described in detail here. Pollen concentration and deposition rate measurements were taken within and downwind from a $20 \times 20 \mathrm{~m}$ maize plot at Montargis, two $24 \times 42 \mathrm{~m}$ maize plots at Grignon and a $500 \times 1000 \mathrm{~m}$ maize plot at Sore (Figure 1). The plots were isolated from other possible sources of maize pollen, except at Montargis. In Grignon, the two plots (plot 1 and 2) were not sown at the same time so pollen measurements were taken at two different flowering dates. Plot 1 was sown on 29 April 2001 and plot 2 on 30 May 2001, both with the cultivar Adonis (Pau Semences S.A, Lescar, France) at a sowing density of 90,000 grains ha ${ }^{-1}$. Plot 1 was surrounded by wheat and by stubble after the wheat was harvested and plot 2 by stubble only. At Sore, a 50 ha commercial field was sown with the cultivar Kalis (Rustica, Mondonville, France) on 18 April 2002 at a sowing density of 85,000 grains $\mathrm{ha}^{-1}$. The maize plot was surrounded by a pine forest (approximately $20 \mathrm{~m}$ high), except for an area of natural grassland (roughly $50 \mathrm{ha}$ ) extending for $500 \mathrm{~m}$ in the prevailing wind direction. The maize field was equipped with a centre pivot-irrigation with a boom length of $500 \mathrm{~m}$ (Figure 1b).

The height of the maize canopy (measured to the top leaf), $h_{\mathrm{c}}$ was $2.3 \mathrm{~m}$ at Montargis, $2.2 \mathrm{~m}$ at Grignon and $2.6 \mathrm{~m}$ at Sore, and the height of the tassels $\left(h_{\mathrm{s}}\right)$ was between 2.2 and $2.5 \mathrm{~m}$ at Montargis, between 2.0 and $2.3 \mathrm{~m}$ at Grignon and between 2.4 and $2.9 \mathrm{~m}$ at Sore. These measurements represent the average of 25 plants in Grignon and 20 plants in Sore.

At Grignon experimental runs lasted about 2 hours each: 8 were made over wheat in plot 1 $\left(\mathrm{S}_{0} 1\right.$ to $\left.\mathrm{S}_{0} 8\right)$; 9 over stubble in plot $1\left(\mathrm{~S}_{1} 9\right.$ to $\left.\mathrm{S}_{1} 17\right)$; and 15 over stubble in plot $2\left(\mathrm{~S}_{2} 18\right.$ to $\left.\mathrm{S}_{2} 32\right)$. More than one experiment was done on each day. Individual runs lasting about 10 hours were carried out at Sore (A1 to A7) over natural grassland on seven different days In the following, $x$ refers to the distance from the downwind edge of the source, and $z$ refers to the height above the ground. 

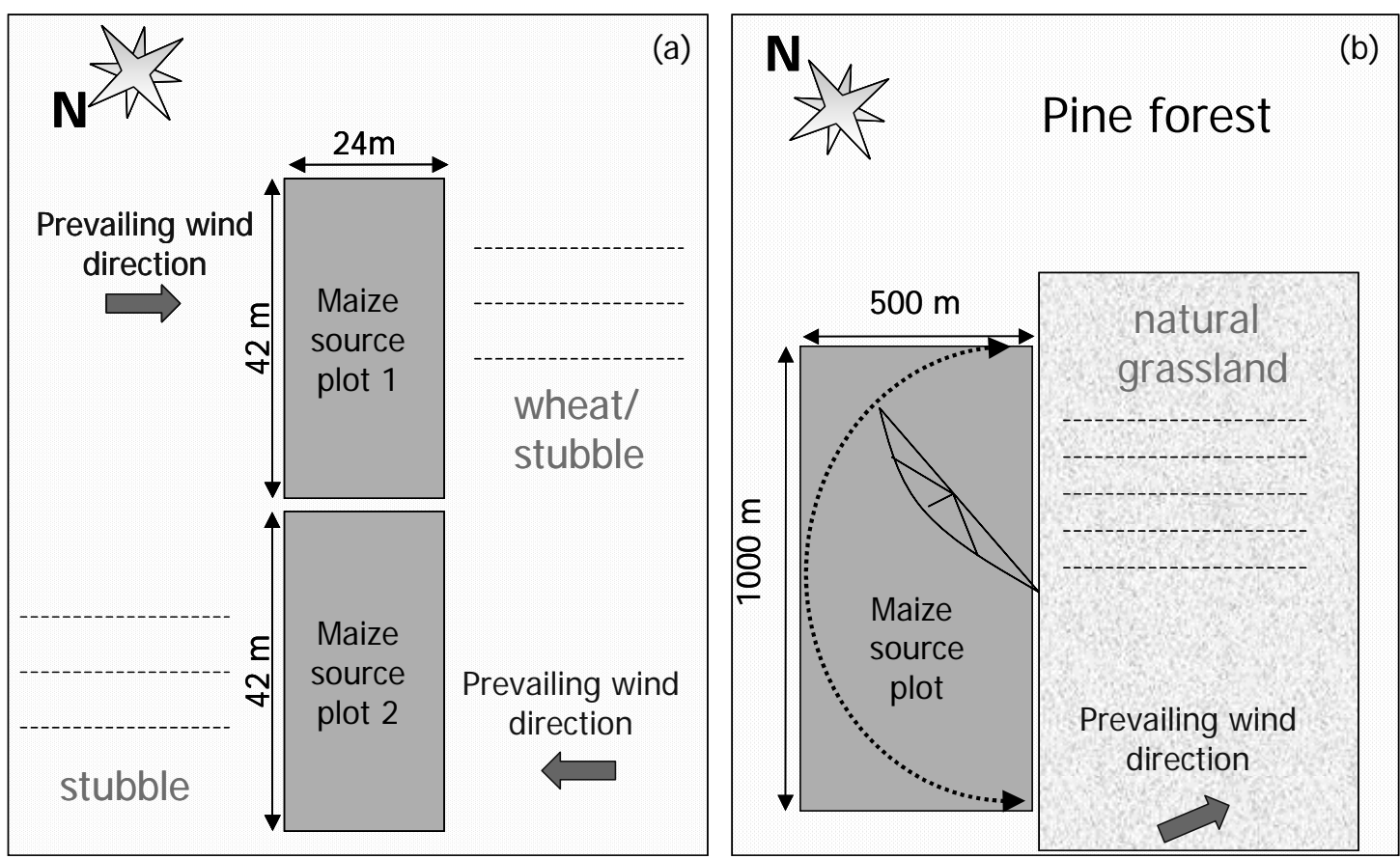

FIGURE 1. Schematic plan of the Grignon 2001 (a) and the Sore 2002 (b) experiments. At Grignon, two $24 \times 42 \mathrm{~m}$ experimental plots were sown on different dates. Plot 1 was surrounded by wheat $\left(\mathrm{S}_{0}\right)$ and stubble after the wheat was harvested $\left(S_{1}\right)$ and plot 2 by stubble $\left(S_{2}\right)$. During runs with plot 1 the mean wind direction was from NE and during runs with plot 2 from SW. In Sore, the crop was $500 \times 1000$ $\mathbf{m}$ (not to scale) and was surrounded by a pine forest, except for an area of about 50 ha of natural grassland on the east extending for $500 \mathrm{~m}$ downwind along the prevailing wind direction. The pivot irrigation system is also shown.

Micrometeorological measurements. Wind speed and direction, air temperature, relative humidity, surface wetness index, global radiation, net radiation, soil heat flux and rain were recorded during the whole pollination period in all experiments. The meteorological masts were located in the maize plot, except at Grignon where global radiation, net radiation, soil heat flux and rain were measured above the wheat/stubble field, in order to obtain the radiation balance of the surrounded area. The friction velocity $\left(u_{*}\right)$ and the Monin-Obukhov length $(L)$ were estimated using measurements of 3D ultrasonic anemometers. At Grignon one anemometer was located $16 \mathrm{~m}$ upwind of plot 1 and was mounted $4.5 \mathrm{~m}$ above the ground. At Sore one anemometer was mounted $6 \mathrm{~m}$ above ground and $20 \mathrm{~m}$ downwind from the maize field. Details of the micrometeorological instruments and measurement methods are reported in (8). All meteorological data were averaged over each run. In addition a wind direction distribution was calculated for each run using the instantaneous wind direction given by $\operatorname{atan}(V / U)$, where atan is the arctangent function, $U$ and $V$ are the instantaneous northern and eastern component of the wind measured with the ultrasonic anemometer. Using these distributions, the standard deviation of the wind direction was estimated by centring the distribution on the mean vector wind direction, and fitting a Gaussian distribution. The total time for 
which the wind was blowing from the maize field was then estimated by integrating the measured distribution over the wind direction range corresponding to the site of interest.

Measurements of pollen production, concentration and deposition rate. Table 1 summarises all pollen measurements made in 2001 and 2002. Daily pollen production was estimated using the method described in (8). Briefly, individual tassels were enclosed in breathable plastic bags and the pollen produced during a 24h period was collected. At Grignon 6 tassels were randomly chosen every day, while at Sore the same 10 tassels were used throughout the experiment. Flowering dynamics were determined from observations on the same 50 plants. The crop pollen production was determined from the daily pollen production convoluted with the flowering dynamics representative of the whole crop (7).

Airborne concentrations were measured continuously during each pollination period using a 7-day recording spore trap (Burkard Manufacturing Co., Rickmansworth, U.K.) placed in the middle of the plot. At Grignon, vertical concentration profiles were measured at 6 heights (Table 1), $3 \mathrm{~m}$ and $10 \mathrm{~m}$ downwind from the source plot, using rotating-arm pollen traps $(8,15)$. Wind speeds were measured at the same heights on the masts in order to estimate the horizontal flux through them. At Sore, to observe longer distances, pairs of rotating-arm pollen traps were placed at $1 \mathrm{~m}$ high, at several distances downwind from the source (Table 1).

Ground deposition rates were estimated using containers filled with an electrolyte solution (Coulter Isoton, Beckman, USA): the containers used at short distances were smaller than those used at remote distances (Table 1). Three deposition measurement replicates were made from $x=1 \mathrm{~m}$ to $32 \mathrm{~m}$ and 2 replicates at $x=60,120$ and $200 \mathrm{~m}$ at Grignon whereas 5 replicates were made at all distances at Sore (Table 1). The number of pollen grains collected was counted using an automatic counter (Coulter Multisize III, Beckman, USA) for short distances, and using a binocular microscope for longer distances. In Sore four additional deposition measurements were made over periods of 4 to 5 days, using 4 containers, one placed 800 m west, one 800 m south, one 1000 m east and one 1000 m north (east being the prevailing wind-direction). 
TABLE 1. Measurements made and methods used during Grignon and Sore experiments. Small containers were $50 \mathrm{~mm}$ in diameter and $70 \mathrm{~mm}$ high in all experiment. Large containers were $170 \mathrm{~mm}$ in diameter and $60 \mathrm{~mm}$ high in Grignon experiment and $117 \mathrm{~mm}$ diameter and $76 \mathrm{~mm}$ high in Sore experiment.

$\begin{array}{lll}\text { Method } & \text { Grignon } & \text { Sore } \\ & \text { Year 2001 } & \text { Year 2002 }\end{array}$

\begin{tabular}{|c|c|c|c|}
\hline \multicolumn{4}{|l|}{ Source } \\
\hline Production & Plastic bags & 6 plants randomly chosen & 10 fixed plants \\
\hline Flowering dynamics & $\begin{array}{l}\text { visual obser- } \\
\text { vation }\end{array}$ & 50 plants & 50 plants \\
\hline Emission dynamics & Burkard & $z=2.5 \mathrm{~m}$ & $z=2.9 \mathrm{~m}$ \\
\hline \multicolumn{4}{|l|}{ Downwind } \\
\hline $\begin{array}{l}\text { Vertical profiles of } \\
\text { concentration at } x=3 \mathrm{~m} \\
\text { and } 10 \mathrm{~m}\end{array}$ & $\begin{array}{l}\text { rotating-arm } \\
\text { traps }\end{array}$ & $\begin{array}{l}\mathrm{S}_{0}: z=1.05,1.35,1.85,2.85,4,6.4 \mathrm{~m} \\
\mathrm{~S}_{1} \& \mathrm{~S}_{2}: z=0.2,0.5,1,2,4,6.4 \mathrm{~m}\end{array}$ & - \\
\hline Concentration at $z=1 \mathrm{~m}$ & $\begin{array}{l}\text { rotating-arm } \\
\text { traps }\end{array}$ & - & $x=10,20,50,125,250,400 \mathrm{~m}$ \\
\hline \multirow[t]{2}{*}{ Deposition at $z=0.3 \mathrm{~m}$} & $\begin{array}{l}\text { small con- } \\
\text { tainers }\end{array}$ & $x=1,2,3,4,8,10,16,32 \mathrm{~m}$ & $x=10,20,50 \mathrm{~m}$ \\
\hline & $\begin{array}{l}\text { large con- } \\
\text { tainers }\end{array}$ & $x=60,120,200 \mathrm{~m}$ & $\begin{aligned} x & =125,250,400 \mathrm{~m} \\
& +x=800,1000 \mathrm{~m}(\mathrm{z}=1.5 \mathrm{~m})\end{aligned}$ \\
\hline
\end{tabular}

Inferred production using the SMOP-2D pollen dispersal model. SMOP-2D is extensively described in (7) and is therefore only briefly described here. It is a Lagrangian stochastic (LS) model in two dimensions $(x, z)$ that simulates the wind dispersion of pollen grains by calculating a large number of individual trajectories. The displacement of individual pollen grains is calculated using the following equations:

$$
\begin{array}{ll}
d u=a_{\mathrm{u}} d t+b_{\mathrm{u}} d \xi_{\mathrm{u}} & d x=u d t \\
d w=a_{\mathrm{w}} d t+b_{\mathrm{w}} d \xi_{\mathrm{w}} & d z=\left(w-V_{\mathrm{s}}\right) d t
\end{array}
$$

$u$ and $w$ are the horizontal and vertical air velocity components; $a_{\mathrm{u}}, b_{\mathrm{u}}, a_{\mathrm{w}}$ and $b_{\mathrm{w}}$ are the Langevin coefficients (functions of the average horizontal and vertical components of air velocity, the horizontal and vertical Eulerian velocity variances, the shear stress and the Lagrangian velocity timescale); $d \xi_{\mathrm{u}}$ and $d \xi_{\mathrm{w}}$ are random numbers drawn from Gaussian distributions with mean zero and variance $d t$; and $V_{\mathrm{s}}$ is the settling velocity of pollen grains (terminal velocity of pollen grains in still air). SMOP-2D considers canopy characteristics: the downwind fetch; the canopy height $\left(h_{\mathrm{c}}\right)$, the roughness length $\left(z_{0}\right)$; the displacement height $(d)$; and the leaf area density $(L A D)$, made up of the horizontal and vertical projections $\left(L A D^{\mathrm{x}}\right.$ and $L A D^{\mathrm{z}}$ ); pollen characteristics (Gaussian distribution of $V_{\mathrm{s}}$ ) as well as micrometeorological variables. The definitions of $z_{0}$ and $d$ can be found in, for example, (16). The model outputs are pollen concentration, and ground and vegetation deposition rates. 
The pollen release rate of the source plot was inferred from vertical concentration profiles measured at $x=3 \mathrm{~m}$ in Montargis and Grignon using SMOP-2D. At Sore the same method was applied using horizontal concentration profiles measured at $z=1 \mathrm{~m}$. The source strength for each simulation was estimated by first running the model with a release rate of 1 grain $\mathrm{m}^{2} \mathrm{~s}^{-1}$ and calculating the concentration profile. Measured concentrations were plotted against calculated concentrations and a linear regression with zero intercept was performed. The slope of this regression was taken as the estimation of the actual source strength.

\section{Results}

Micrometeorological conditions. The weather was dry and generally sunny (high global radiation) at both Grignon and Sore experiments, conditions suitable for maize pollination $(8,17)$. Wind speeds were low $\left(U=1.9-4.7 \mathrm{~m} \mathrm{~s}^{-1}\right)$ for the $\mathrm{S}_{0}$ and $\mathrm{S}_{1}$ runs and high $(U=2.6-$ $\left.7.2 \mathrm{~m} \mathrm{~s}^{-1}\right)$ for the $S_{2}$ runs at Grignon, but were very low $\left(U=0.5-1.4 \mathrm{~m} \mathrm{~s}^{-1}\right)$ for all runs at Sore. The friction velocity, $u *$, ranged from 0.21 to $0.71 \mathrm{~m} \mathrm{~s}^{-1}$ and from 0.12 and $0.41 \mathrm{~m} \mathrm{~s}^{-1}$ at Grignon, and Sore respectively. All runs were under fairly unstable stratification $(L<0)$ except runs $\mathrm{S}_{0} 3, \mathrm{~S}_{0} 6, \mathrm{~S}_{1} 12, \mathrm{~A} 3, \mathrm{~A} 4$ and $\mathrm{A} 5$ where conditions were close to those of free convection (low $u *$ and $L \approx 0$ ). The mean wind direction was less than $35^{\circ}$ from the direction of the sampling lines for 14 of the 32 runs at Grignon and for 5 of the 7 runs at Sore. However the wind direction was more variable in Sore than in Grignon: the standard deviation in wind direction was greater than $35^{\circ}$ for 7 runs at Grignon, but exceeded this for all the runs at Sore. This could have been partly due to the larger sampling time at Sore. Full details of the micrometeorological conditions are found in the Supporting Information section on the ES\&T web site.

Pollen production and emission dynamics. In Grignon, pollen production began on 20 July 2001 and lasted 13 days for plot 1, with the maximum on 27 July, and it began on 9 August 2001 and lasted 9 days for plot 2, with the maximum on 14 August. In Sore, pollen production started on 15 July 2002 and lasted 13 days with the maximum on 21 July. Total pollen production was $6.6 \times 10^{6}$ grains per tassel for plot 1 and $6.3 \times 10^{6}$ for plot 2 at Grignon, and $6.7 \times$ $10^{6}$ grains per tassel at Sore (Figure 2).

Figure 2 also shows the two-hourly moving average of pollen concentration measured continuously in the crop during the pollinating period at Grignon and Sore. The highest concentrations were around 230 grains $\mathrm{m}^{-3}$ for plot 1, 450 grains $\mathrm{m}^{-3}$ for plot 2 at Grignon and 370 
grains $\mathrm{m}^{-3}$ at Sore. In Grignon, the dynamics of pollen concentration was similar for the two plots, with the largest concentration observed in the first 4 to 5 days of pollination. In contrast, at Sore, the concentration remained small for the first 6 to 7 days of pollination and then increased towards the end of the pollination period. This was probably due to irrigation which was sometimes just above the Burkard trap, as marked with arrows in the Figure 2c. It may also be linked with the larger spatial variability in pollen production in Sore.

The average daily pattern of pollen concentration is shown for the experiments at Montargis, Grignon and Sore in Figure 3. The two-hourly averaged pollen concentrations for each day were normalised by dividing by the maximum pollen concentration of that day, and the normalised values averaged over the pollination period. The patterns were similar between years, but with slight differences: pollen release usually started at around 8:00 UT and lasted until about 18:00 UT with the maximum occurring between 11:00 and 12:00 UT. At Grignon and Montargis, the maximum was reached earlier and the magnitude was higher than at Sore. At Grignon, a second peak was observed at around 16:00 UT for plot 1. 

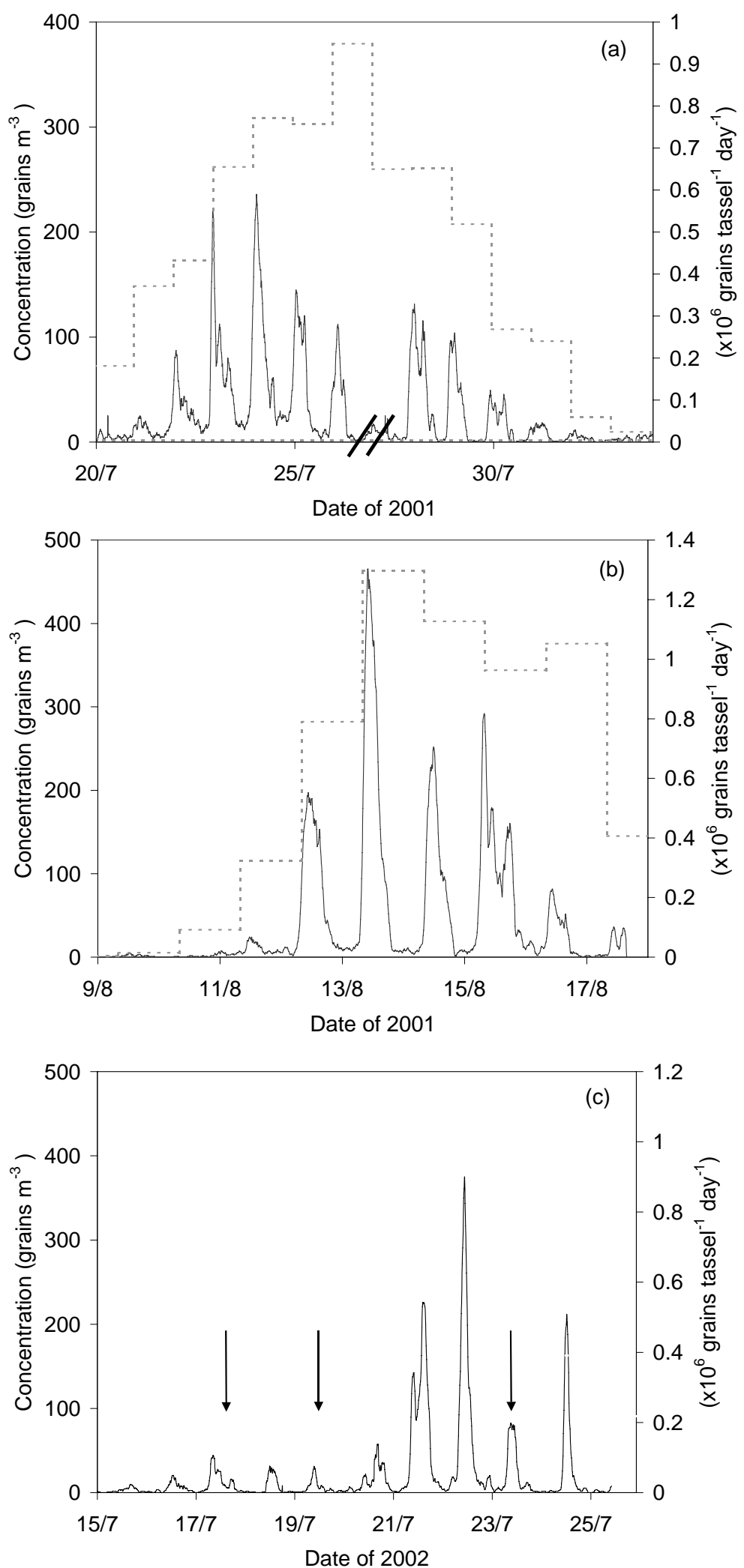

FIGURE 2. Two-hourly moving average airborne pollen concentration measured above the source plot using a Burkard trap (continuous line) together with the estimated daily pollen production (dotted line) for (a) plot 1 and (b) plot 2 of the Grignon experiment and (c) the Sore experiment. The double bar in (a) denotes that on the 27 July, the Burkard was disconnected during wheat harvest around the maize plot. The arrows in (c) denote days when the center pivot-irrigation system was just above the Burkard trap. 


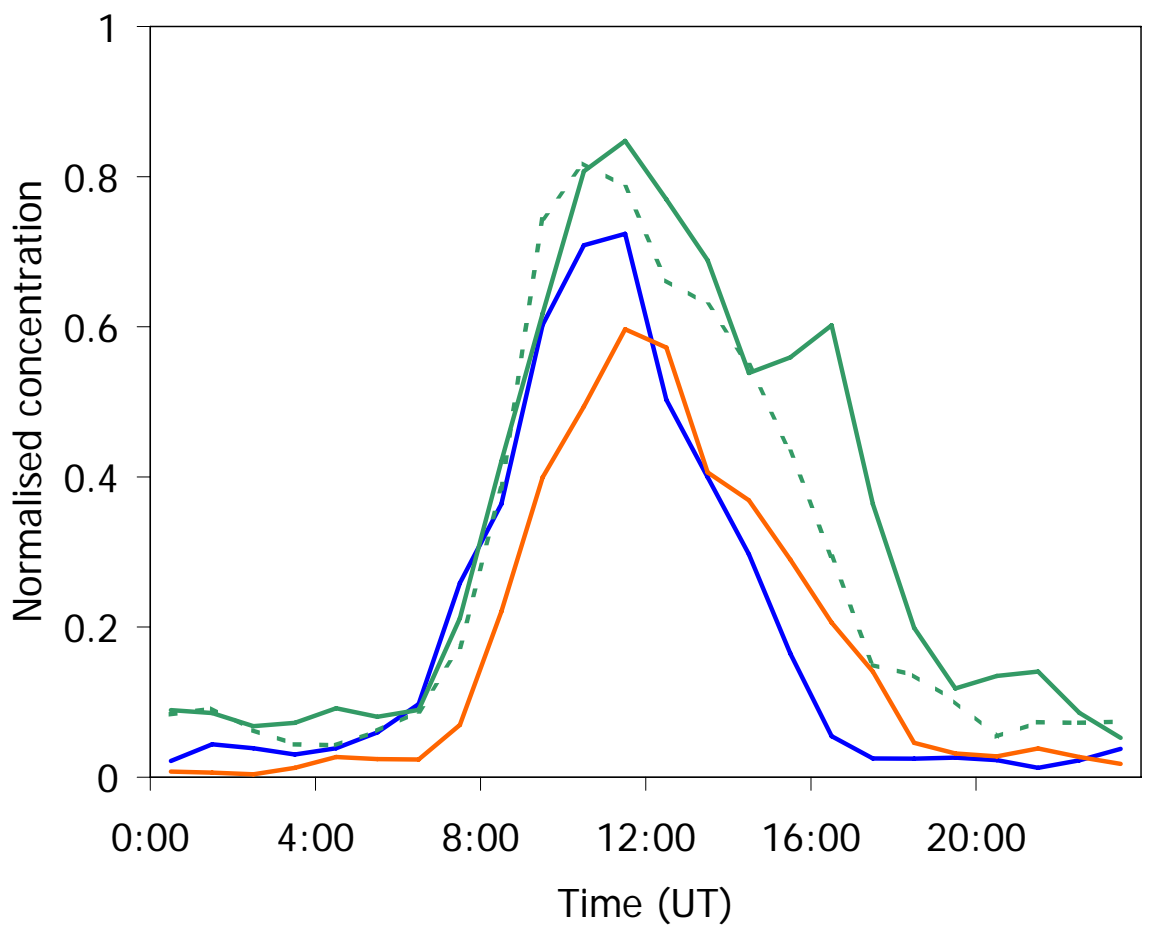

FIGURE 3. Averaged daily dynamics of pollen concentration above the source plot in: Montargis between the 29 July and 2 August 2000 (blue line); Grignon between the 24 and 28 July 2001 (green line); Grignon between the 11 and 17 August 2001 (green dotted line); and Sore between the 21 and 24 July 2002 (orange line). Two-hourly averaged concentrations were normalised for each day by dividing by the daily maximum for that day. Normalised values were averaged over the pollen production period.

The two-hourly averaged pollen concentrations are shown for Grignon between the 22 and 25 July, together with the surface wetness index, SWI, and the vapour pressure deficit, VPD, in Figure 4. Pollen release usually started as dew disappeared (SWI sharply diminishing from nearly $100 \%$ (wet) to nearly $0 \%$ (dry)) and vapour pressure deficit began to increase, except for the 23 July 2003, when there was no dew during the previous night. Note, in all experiments, the concentration at night did not fall to zero suggesting that pollen may have been resuspended. 


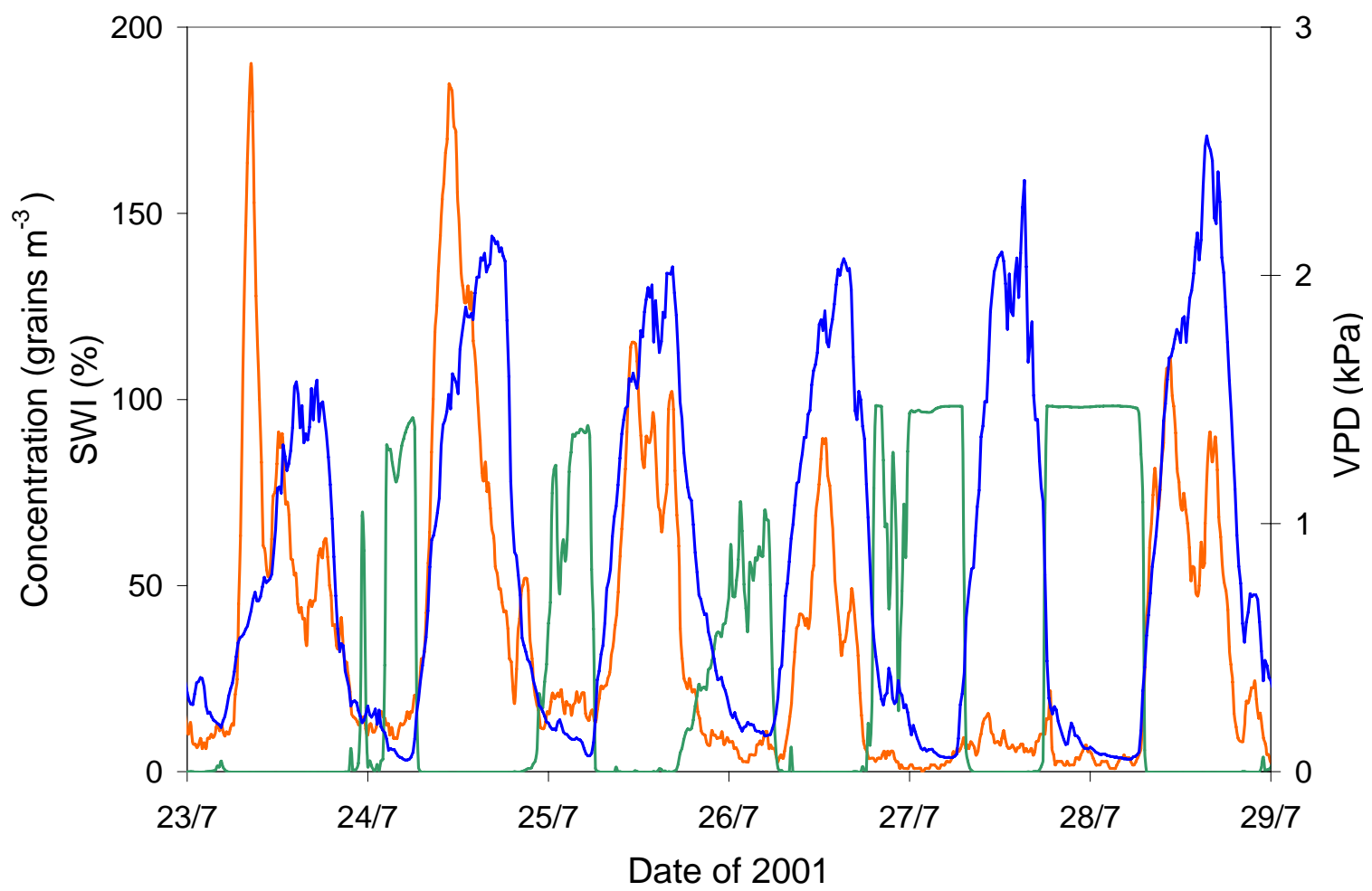

FIGURE 4. Two-hourly pollen concentration (orange line), surface wetness index SWI (green line) and the vapour pressure deficit VPD (blue line) for plot 1 in Grignon between 23 and 28 July 2001.

Pollen concentration and deposition rates downwind from the source. Figure 5a shows the average vertical pollen concentration profiles downwind from the source for Montargis and for plot 1 and plot 2 at Grignon. The maximum average concentration was 58 (range 0 164) grains $\mathrm{m}^{-3}$ and $116(0-389)$ grains $\mathrm{m}^{-3}$ for plot 1 and plot 2 , respectively at $x=3 \mathrm{~m}$ and $21(0-50)$ grains $\mathrm{m}^{-3}$ and $45(0-140)$ grains $\mathrm{m}^{-3}$ at $x=10 \mathrm{~m}$. At $x=3 \mathrm{~m}$, concentrations values were directly influenced by source strength, in contrast, at $x=10 \mathrm{~m}$, they were more influenced by wind speed. The horizontal flux of pollen, $F(z)$, at height $z$ passing through the masts at $x=3 \mathrm{~m}$ and $x=10 \mathrm{~m}$ was estimated using $F(z)=C(z) U(z)$ where $C$ is the concentration and $U$ is the mean horizontal wind speed (Figure 5b). Maximum average horizontal fluxes were 60 (range 0 - 185) grains $\mathrm{m}^{-2} \mathrm{~s}^{-1}$ for plot 1 and $180(2-490)$ grains $\mathrm{m}^{-2} \mathrm{~s}^{-1}$ for plot 2 at $x=3 \mathrm{~m}$ and $32(0-71)$ grains $\mathrm{m}^{-2} \mathrm{~s}^{-1}$ for plot 1 and $81(0-214)$ grains $\mathrm{m}^{-2} \mathrm{~s}^{-1}$ for plot 2 at $x=10 \mathrm{~m}$. At Montargis and for plot 1 at Grignon the maximum flux was observed at about the height of the tassels at $x=3 \mathrm{~m}$ but was generally lower at $x=10 \mathrm{~m}$, showing the settling of the pollen plume. However, the height of maximum flux at both 3 and $10 \mathrm{~m}$ was similar for plot 2 at Grignon probably due to higher wind speed during these experiments, although fluxes were on average twice as large as at Montargis and plot 1. Moreover, horizontal fluxes were not zero at the highest measurement point (4 m in Montargis and $6.5 \mathrm{~m}$ in Grignon), indicating that detectable amounts of pollen were transported above these heights. 

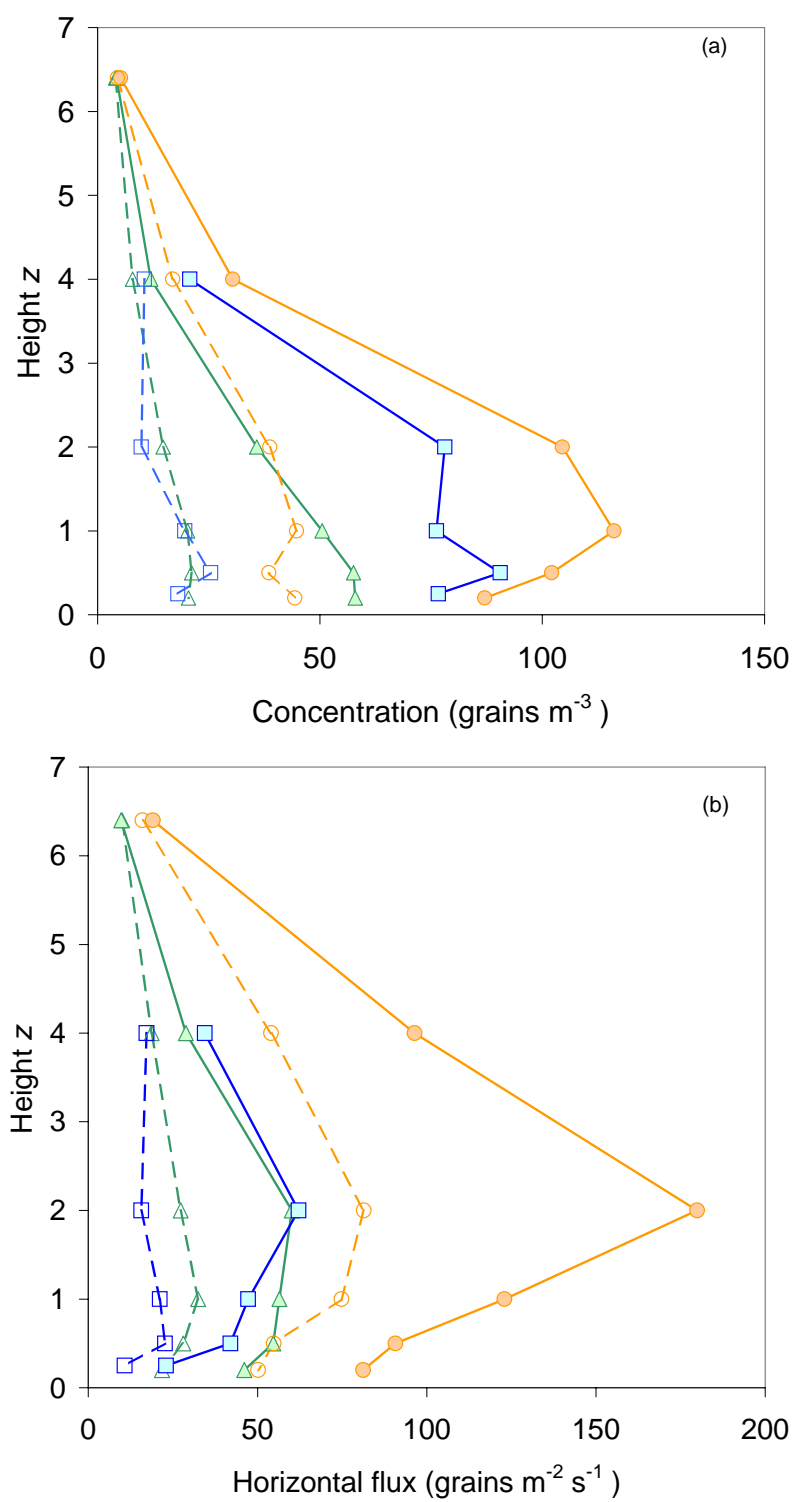

FIGURE 5. Average vertical pollen concentration profiles (a) and horizontal flux profiles (b) for Grignon plot 1 (green triangles), Grignon plot 2 (orange circles) and Montargis (blue squares). Filled symbols represent measurements at $x=3 \mathrm{~m}$ and open symbols at $x=10 \mathrm{~m}$. Averages were made over 9 measurements for plot 1, 15 for plot 2 and 12 for Montargis.

Figure 6 shows pollen concentration measured downwind from the source at Sore. The values are of the same order of magnitude as for Montargis and Grignon. The largest values were found during runs $A_{2}$ and $A_{5}$. During run $A_{2}$ the average wind direction lays along the line of measurement, but the source strength was low; for run $A_{5}$ the average wind direction was at an angle to the line of measurement but the source strength was high. Wind direction was less favourable for the other days, particularly for runs $A_{3}$ and $A_{6}$ where the pivot-irrigation system was just in front of line of measurement. 


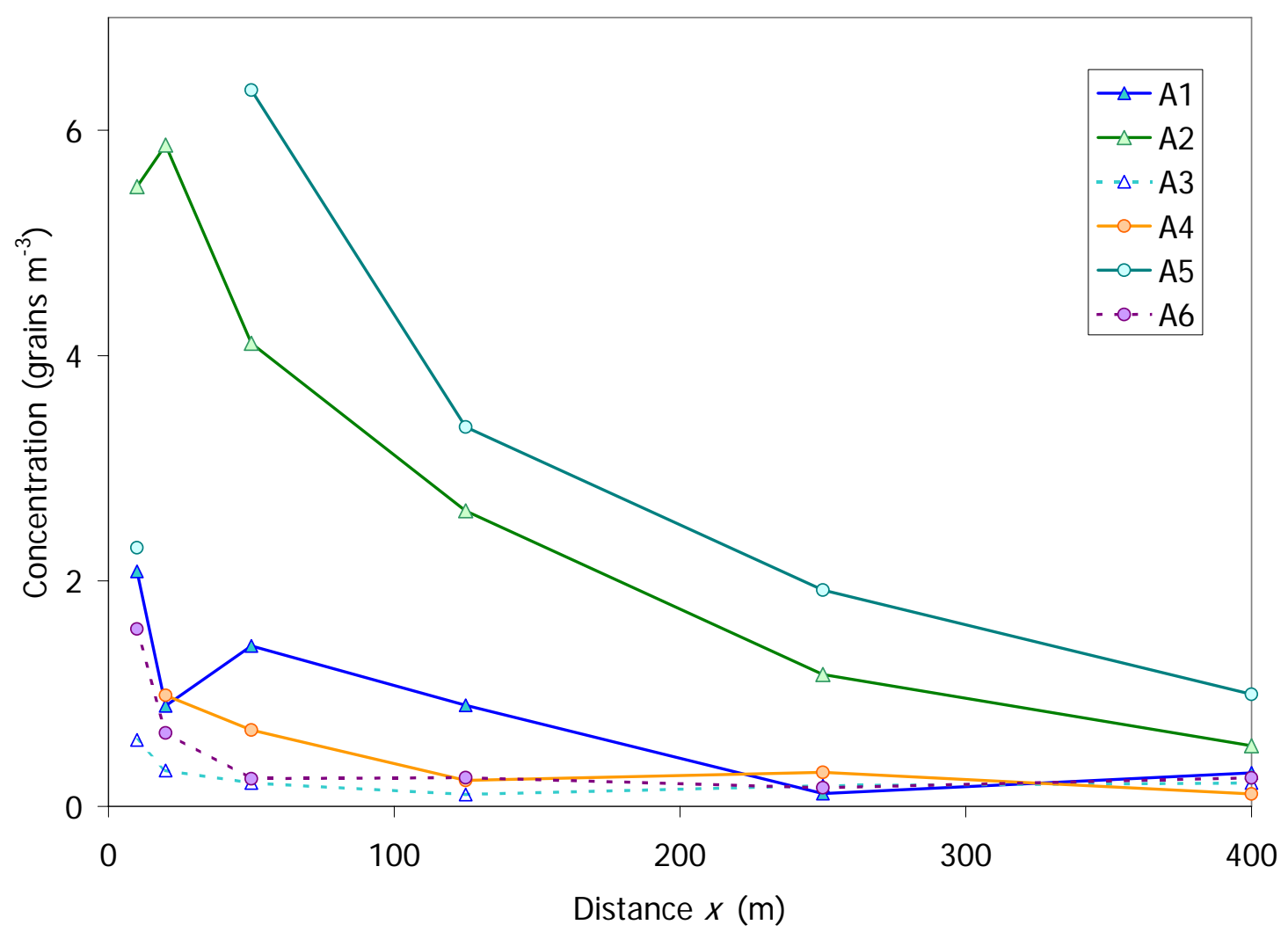

FIGURE 6. Mean pollen concentration measured downwind from the source, at $z=1 \mathrm{~m}$ height, in Sore. Each measurement corresponds to a separate day. Dotted lines denote runs where the pivot-irrigation was in front of the measurement line.

Figure 7a shows the pollen deposition gradients for all runs at the three sites. The deposition rates have been normalised by dividing by the deposition rate at $x=10 \mathrm{~m}$, and the downwind distances have been normalised by dividing by the roughness length of the downwind field $z_{0}$. At Montargis and Grignon $z_{0}$ was estimated from the wind profile at $x=10 \mathrm{~m}$ and at Sore from the sonic anemometer measurements. $z_{0}$ was $0.03 \mathrm{~m}$ at Montargis, 0.07 over wheat for Grignon $S_{0}, 0.02$ and 0.01 over stubble for Grignon $S_{1}$ and Grignon $S_{2}$, respectively, and 0.04 over natural grassland at Sore. Figure 7b shows the frequency distribution of deposition rates at $x=10 \mathrm{~m}$ downwind for each experiment. It ranged between 10 and 100 grains $\mathrm{m}^{-2} \mathrm{~s}^{-1}$. Pollen deposition rates decreased rapidly with distance and varied between and within experiments. Interestingly, the shape of the normalised deposition rate gradient was similar, though, not the same, for the three experiments, even when the source size and intensity were different. Deposition rates measured 800 and $1000 \mathrm{~m}$ downwind from the source ranged from 0.001 to 0.0002 grains $\mathrm{m}^{-2} \mathrm{~s}^{-1}$. 

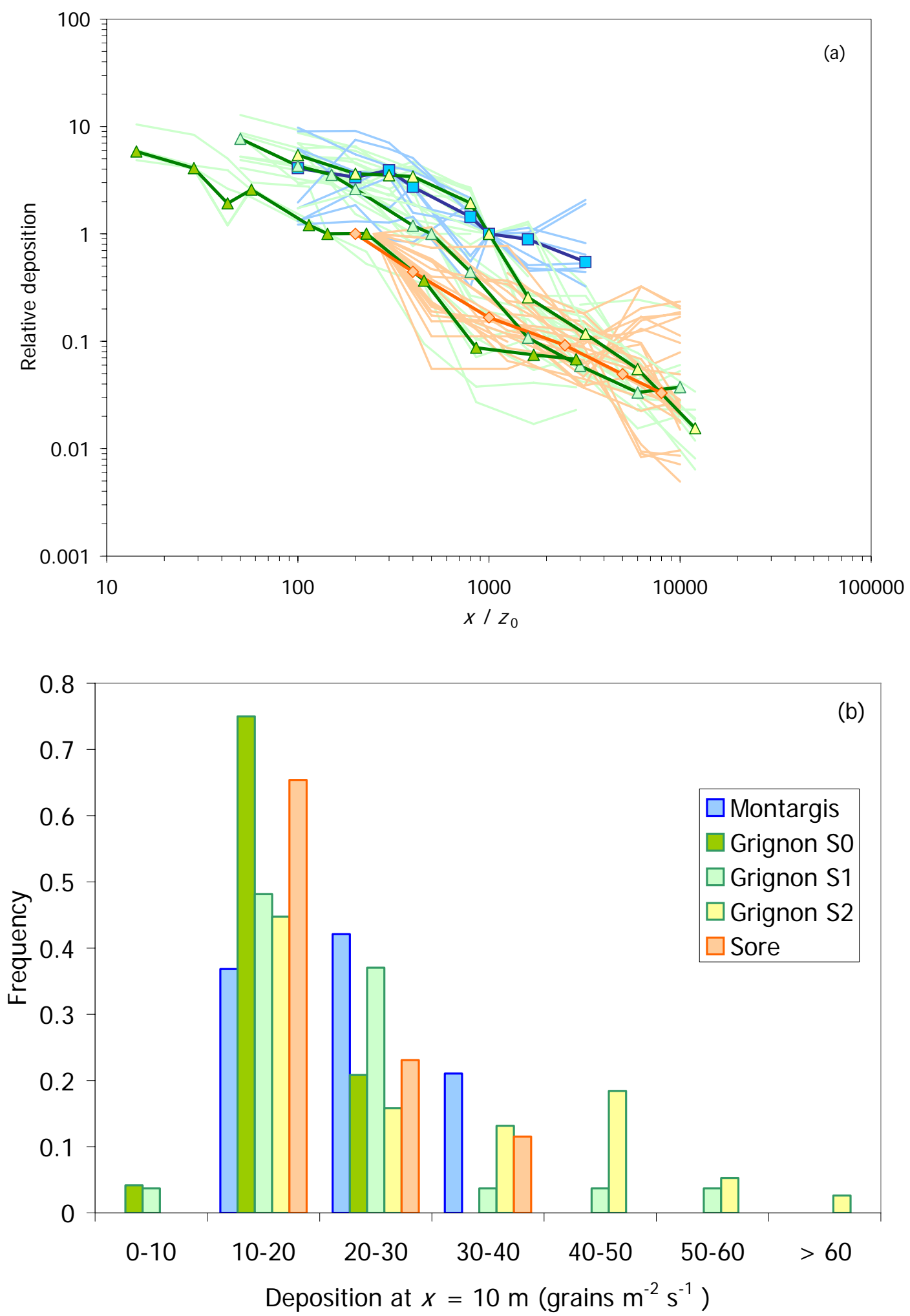

FIGURE 7. (a) Pollen deposition rates normalised by deposition at $x=10 \mathrm{~m}$, as a function of the downwind distance $x$ normalised by the roughness length $z_{0}$ for each of the runs in Montargis (blue lines), Grignon (green lines) and Sore (orange lines). The median normalised deposition rates are also shown for Montargis (squares), Grignon (green $\left(S_{0}\right)$, light green $\left(S_{1}\right)$ and yellow $\left(S_{2}\right)$ triangles) and Sore (diamonds). The roughness length $z_{0}$ was $0.01 \mathrm{~m}$ at Montargis, 0.07 for $S_{0}, 0.02$ for $S_{1}$ and 0.01 for $S_{2}$ at Grignon and 0.04 at Sore. (b) Frequency distribution of pollen deposition rates at $x=10 \mathrm{~m}$ for Montargis (blue bars), for Grignon (green, light green and yellow bars) and Sore (orange bars). 


\section{Discussion}

Pollen release rate and pollen production. This study has shown that maize pollen grains can be dispersed considerable distances $(1000 \mathrm{~m})$ downwind from maize crops. The estimation of the amount of pollen release is consequently of paramount importance to determine the amount of pollen available for long distance dispersal. Figure 8 shows release rates inferred from SMOP-2D as a function of measured pollen production. Measured release rates were 4 to 100 times larger for Sore, but, were in agreement for Grignon $S_{1}$ and $S_{2}$ and they were down to 10 times smaller for Montargis. These discrepancies may be due to many factors, either linked with the model uncertainty or the specific conditions of each experiment.

The misalignment of the wind direction with the row of instruments and the wind direction variability may explain some of the observed discrepancies in Sore, due to the fact the SMOP2D is a two-dimensional model (along wind and vertical directions). Indeed, SMOP-2D ideally requires that the wind blows perpendicularly to the edge of the crop, and that the distance downwind is smaller than the crosswind crop size. At Sore, the four runs (A3-A6), where the model greatly underestimated pollen production, corresponded to the four cases where the wind direction was away from the "correct" direction for more than $30 \%$ of the time. In the other cases, the wind direction was along the measurement line for more than $90 \%$ of the time. In Sore, if the modelled production is "corrected" by dividing by the percentage of time the wind blew along the correct direction (See Supporting Information for more details), the modelled production becomes 2 to 20 times smaller than measured production (instead of 4 to 100). This remaining underestimation either means that the deposition within the canopy was not well modelled, or that measured production was artificially large.

However, other factors may have played a role. For example, at Sore, the pivot irrigation probably reduced pollen release due to washout. Also at Sore the longer sampling period (10 hours compared to 2 hours in other experiments) may make the model assumptions inappropriate, particularly due to changes in wind direction. Alternatively, the method used to estimate pollen production may have overestimated it by altering the microclimate around the tassels or introducing bias in the choice of plants and the size of sample. At Montargis and Sore, the same plants were used during the whole pollination period whereas at Grignon plants were randomly chosen on each day. This supports the fact that the model especially underestimated the pollen production at Sore and Montargis. 
The heterogeneity of the maize plots may also explain some of the discrepancies. Above homogeneous surfaces, dispersion models have proven to be useful and accurate for inferring source strengths from measured concentrations of gases $(18,19)$ and spores $(20)$. However, when the surface is heterogeneous or when there are large variations in roughness, the problem becomes much more difficult, even for gases (21). For particles, accurate knowledge of the settling velocity $\left(V_{\mathrm{s}}\right)$ is also required. Recent work has shown that maize pollen may have complex distributions of $V_{\mathrm{s}}$, leading to additional difficulties in inverting dispersal models to estimate source strengths (22).

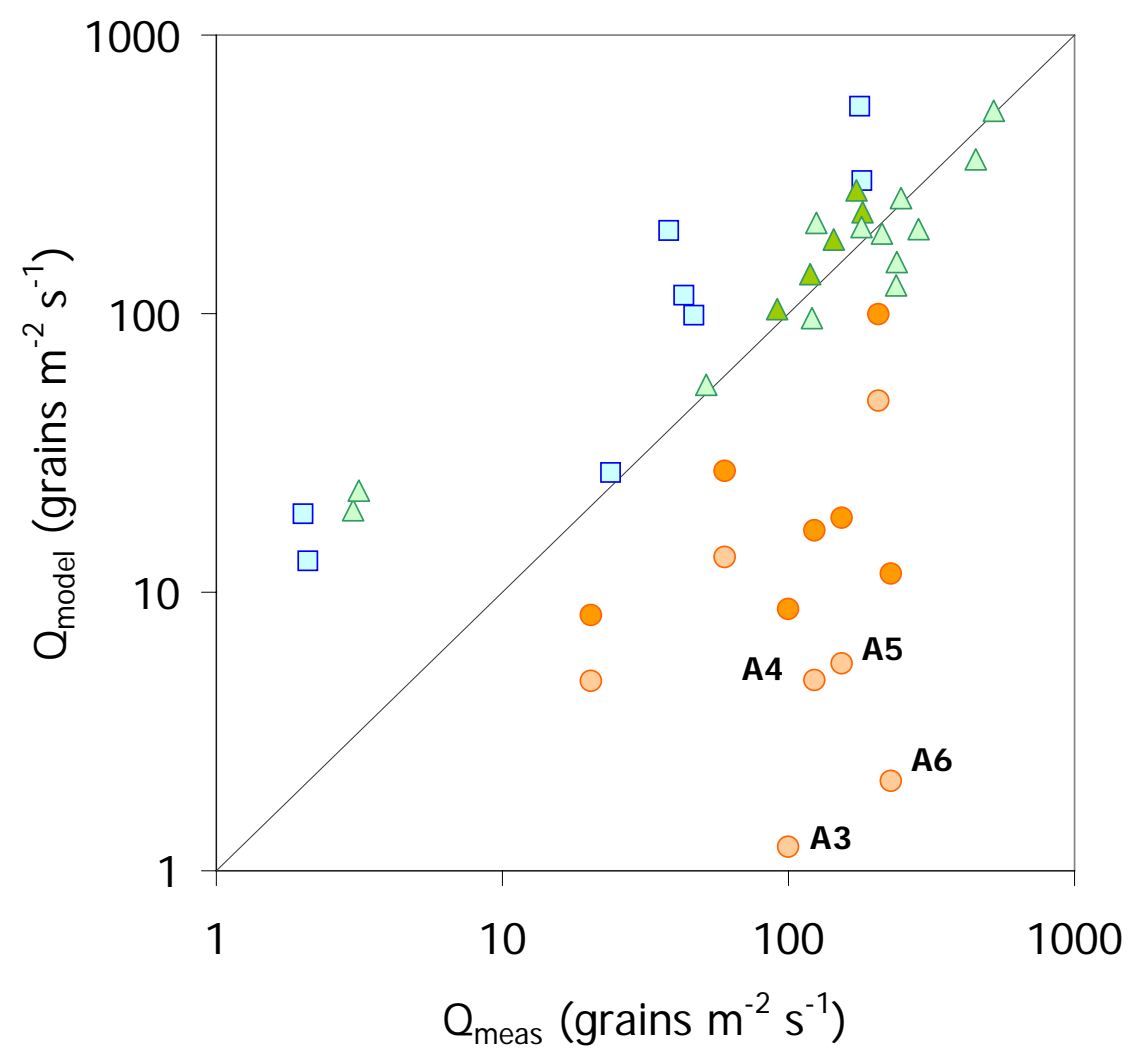

FIGURE 8. Pollen release rate $\left(Q_{\text {model }}\right)$ inferred using the SMOP-2D dispersal model versus measured pollen production rates $\left(Q_{\text {meas }}\right)$, for Montargis (blue squares), Grignon $S_{1}$ (green triangles), Grignon $S_{2}$ (light green triangles) and Sore (light orange circles). The letters refer to individual experiments at Sore. Orange circles refer to $Q_{\text {meas }}$ corrected for wind direction (see text).

Influence of environmental factors on the daily dynamics of pollen release. It was observed at Montargis that pollen release started in the morning as the crop dried (8). The results from Grignon (Figure 4) confirm this, as the timing of pollen release is correlated with the increase of VPD and the drying of the surface during the morning. Pollen release began once a threshold VPD (around 0.2 to $0.5 \mathrm{kPa}$ ) was passed. This also explains why the release started much earlier if no dew was formed at night. 
Intermediate-distance dispersal. Horizontal fluxes at $x=3 \mathrm{~m}$ and $10 \mathrm{~m}$ were integrated between the ground to the upper height of the measurements. The integrated flux at $x=10 \mathrm{~m}$ is plotted against the flux at $x=3 \mathrm{~m}$ in Figure 9. The flux at $10 \mathrm{~m}$ was 0.5 times the flux at 3 $\mathrm{m}$ at Grignon and 0.4 times at Montargis. The apparent higher proportion of pollen flux reaching $10 \mathrm{~m}$ observed at Grignon was probably due to the lower maximum height of the measurement made at Montargis (which was thus missing a part of the horizontal flux that was measured in Grignon). It is interesting that the ratio of fluxes at 3 and $10 \mathrm{~m}$ was more or less constant, although the magnitude of the fluxes and the experimental conditions varied greatly. Figure 9 suggests that in many conditions, $50 \%$ of the pollen that achieved $x=3 \mathrm{~m}$ also reached at least $x=10 \mathrm{~m}$, which means that the sum of the fraction of pollen deposited and that passing above $6.5 \mathrm{~m}$ between $x=3$ and $10 \mathrm{~m}$ always equals the fraction passing through $x=10 \mathrm{~m}$. It is also interesting that the horizontal flux at $z=6.5 \mathrm{~m}$ was similar at both 3 and $10 \mathrm{~m}$ (Figure 5) which indicates that a significant fraction of the pollen had been transported above this height.

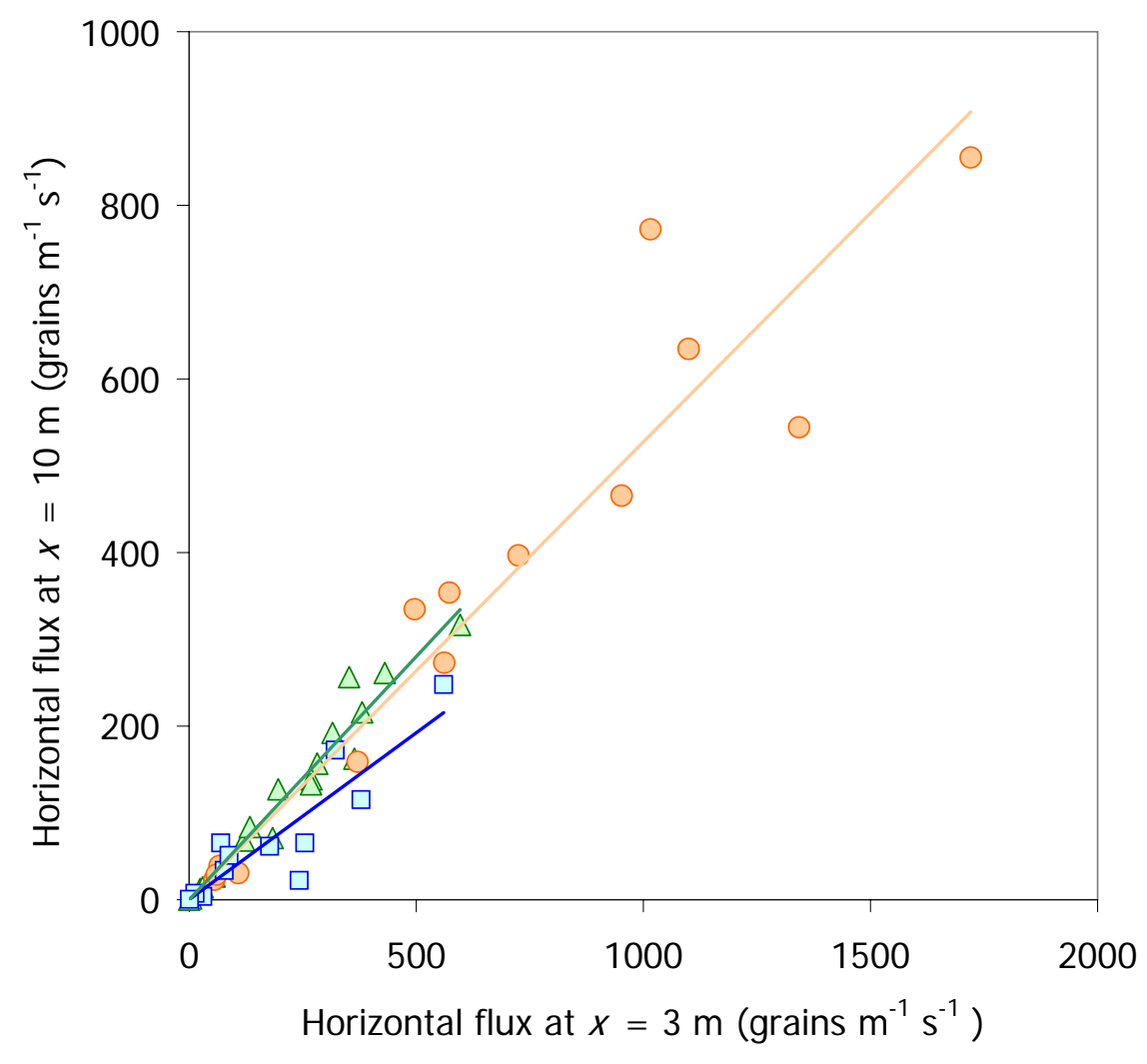

FIGURE 9. Integrated horizontal flux at $x=10 \mathrm{~m}$ downwind from the source as a function of the integrated horizontal flux at $x=3 \mathrm{~m}$. Three experiments are shown: Grignon $S_{1}$ (green triangles), Grignon $S_{2}$ (orange circles) and Montargis (blue squares). The lines are the linear regressions with zero intercept, they were $y=0.5 x$ for Grignon $S_{1}, y=0.5 x$ for Grignon $S_{2}$ and $y=0.4 x$ for Montargis. 
Long-distance dispersal. Horizontal deposition gradients are generally better described by a power $\left(a x^{b}\right)$ than an exponential $\left(a \mathrm{e}^{-b x}\right)$ function of distance (23). Deposition rates decreased with distance according to a power law of the form $\sim a x^{\mathrm{b}}$. At Sore, $a=9,11,2,4,10,3,14$ and $b=-1,-0.9,-0.5,-0.8,-1,-0.5,-1.2$ for $A_{1}$ to $A_{7}$ respectively and was consistent with the data from (9). However, it should be stressed that the wind direction would have had a great effect on concentrations and deposition rates measured along a straight line downwind from the source. Indeed, large standard deviations in wind direction will enhance the decrease of concentration and deposition rate with distance. Moreover, since the standard deviation of wind direction is dependent upon thermal stratification (24), the form of power law function would probably change with thermal stratification.

Deposition rates measured at 800 and $1000 \mathrm{~m}$ from the maize plot at Sore were substantially less (1000 times lower at $1000 \mathrm{~m}$ ) than would be expected from extrapolation of the power law relationships derived using the measurements made closer to the source. These differences probably appeared because the sampling points were not always along the downwind fetch from the field and the deposits were measured over a long period including nights (when small amounts of pollen would have been produced). However, these measurements probably represent more realistic estimates of deposition rates found at longer distances under real situations.

Measured deposition velocities, $V_{\mathrm{d}}\left(V_{\mathrm{d}}=\right.$ Concentration $/$ Deposition $)$, are plotted against downwind distance in Figure 10. $V_{\mathrm{d}}$ ranged from 0.2 to $0.7 \mathrm{~m} \mathrm{~s}^{-1}$, which is 1 to 3 times greater than the settling velocity $V_{\mathrm{s}}$. Published values of $V_{\mathrm{s}}$ range from $0.2 \mathrm{~m} \mathrm{~s}^{-1}$ to $0.3 \mathrm{~m} \mathrm{~s}^{-1}(25,26)$. Values of $V_{\mathrm{d}}$ are higher than $V_{\mathrm{s}}$ close to the source $(x<50 \mathrm{~m})$ which correspond to distances where pollen dispersal is still under the influence of the roughness change. The enhancement observed deposition could be explained by the negative vertical air velocity found downwind from a rough-to-smooth change, and by enhanced magnitude and gradients of turbulent kinetic energy in the transition zone. A sensitivity analysis has shown that high $V_{\mathrm{d}}$ near the source could not only be explained by the presence of clusters of pollen (7). 


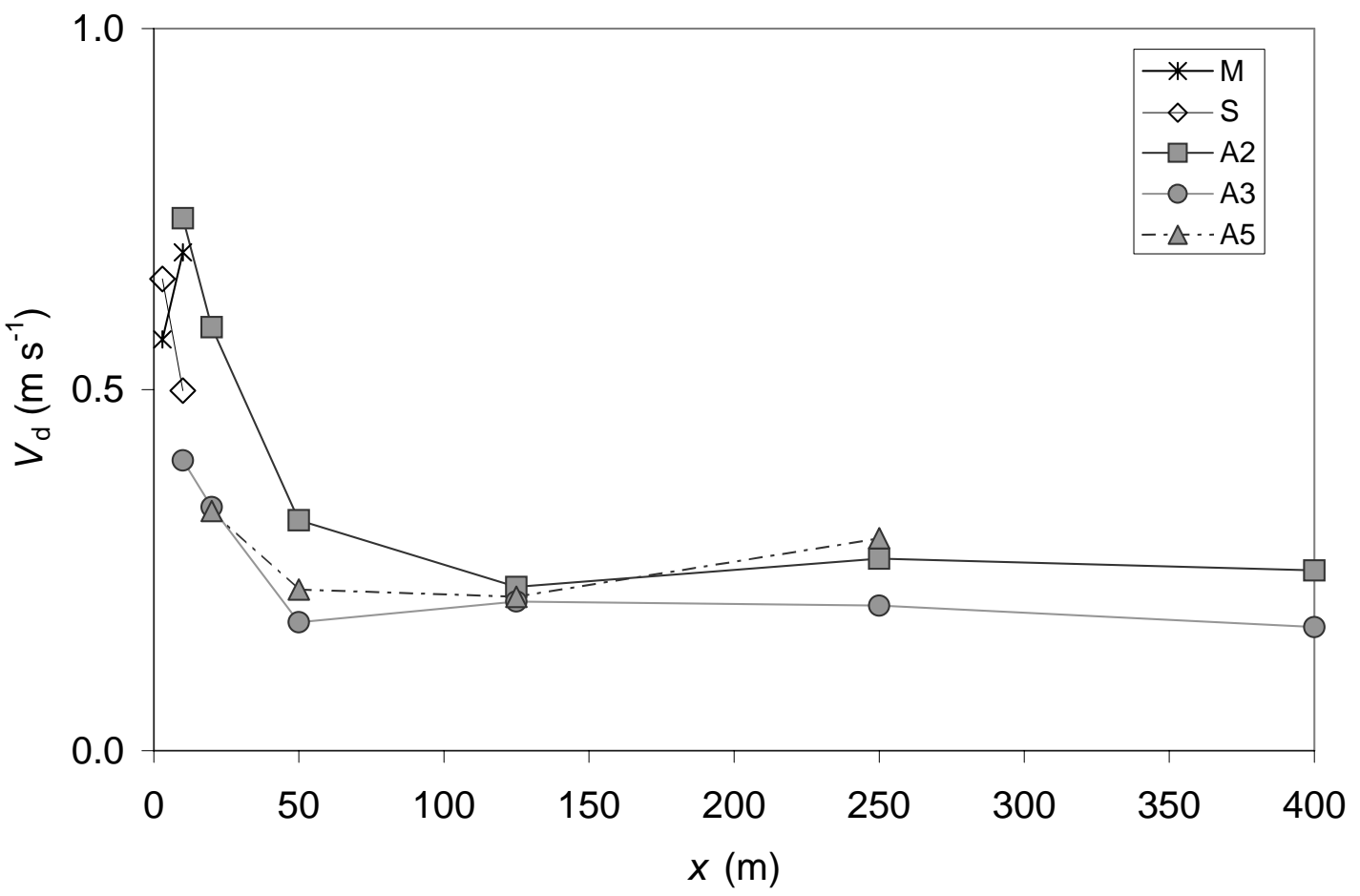

FIGURE 10. Deposition velocity $V_{d}\left(V_{d}=\right.$ Concentration / Deposition) as a function of the downwind distance at Montargis (M), Grignon (S) and Sore (A2, A3 and A5). Results at Montargis and Grignon were averages of all runs.

Influence of the downwind roughness and the roughness change on deposition rates.

Deposition rates normalised by the deposition rate at $x=10 \mathrm{~m}$ are presented as functions of the downwind distance divided by the roughness length of the downwind area (Figure 11a) and the height of the source canopy, which is representative of the roughness change (Figure 11b). These graphs show that pollen deposition scales with the height of the canopy near the source $\left(x / h_{\mathrm{c}}<10\right)$ and with the roughness of the downwind field $\left(z_{0}\right)$ at farther distances $\left(x / z_{0}>2000\right)$. This is consistent with the fact that the higher the source is, the further the pollen can travel (near the source), whereas at longer distances, the pollen plume becomes more homogeneous and its deposition is governed by the surface characteristics $(27,28)$. On average, $h_{\mathrm{c}}$ is a better scaling parameter for the deposition rate than $z_{0}$ for the usual distances of interest (isolation distances).

However, it is difficult to draw definite conclusions on the real effect of roughness as the number of observations is limited, and the data scattered. This aspect should rather be investigated using dispersion models. 

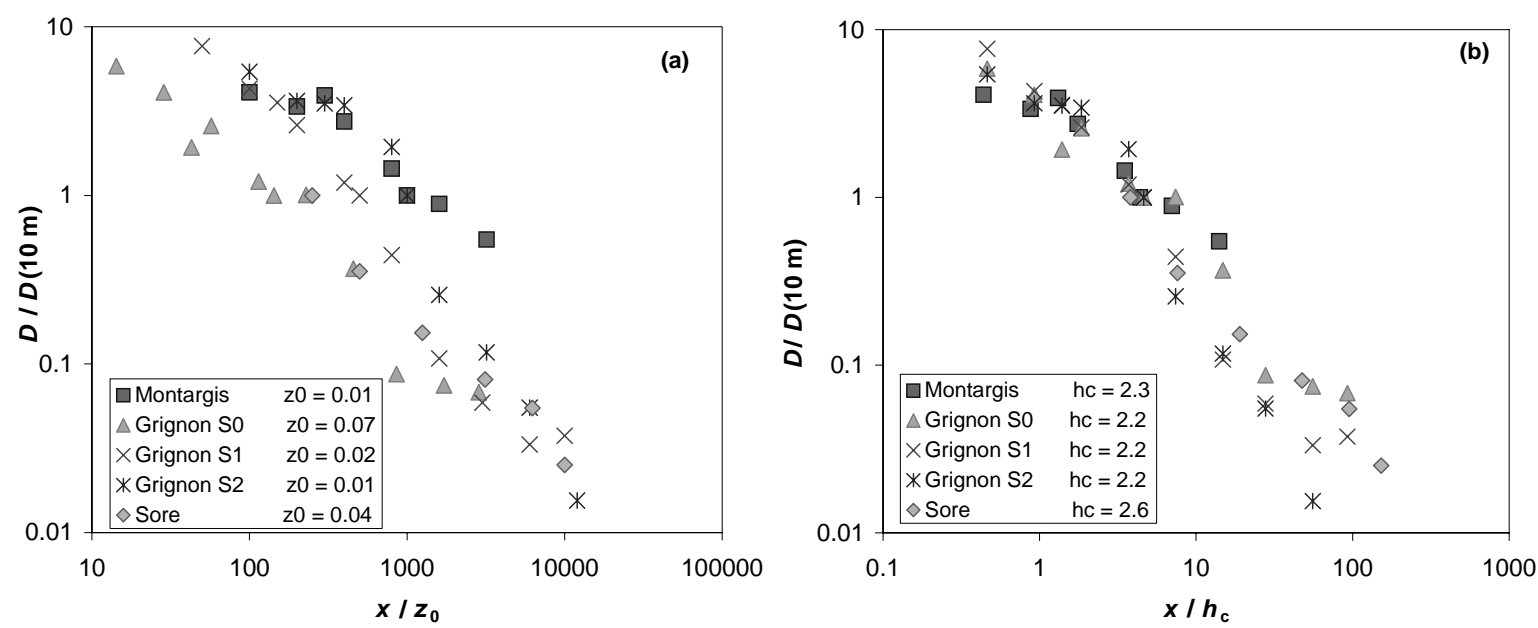

FIGURE 11. Relative deposition normalised by deposition at $x=10 \mathrm{~m}$ as a function of relative downwind distance normalised by (a) the roughness length, $z_{0}$ and (b) by the canopy height, $h_{c}$ for all experiments.

\section{Acknowledgements}

We thank Mr Boulon for allowing measurements to be made on his farm. This work was funded by INSU / CNRS, Convention $\mathrm{N}^{\circ} 01 \mathrm{CV}$ 081, as well as by INRA (Institut National de la Recherche Agronomique), FNPSMS (Fédération Nationale de la Production des Semences de Maïs et Sorgho) and GNIS (Groupement National Interprofessionel des Semences et plants).

\section{Supporting information}

A detailed description of the micrometeorological conditions encountered during each run in the Grignon and Sore experiments.

\section{Literature Cited}

(1) James, C., Global Status of Commercialized Transgenic Crops: 2003. ISAAA Briefs $n^{\circ} 30,2003$; available at http://www.isaaa.org/kc/CBTNews/press_release/briefs30/ es_b30.pdf (accessed November 8, 2004).

(2) Paterniani, E.; Stort, A. C. Effective maize pollen dispersal in the field. Euphytica 1974, 23, 129-134.

(3) Luna, V. S.; Figueroa, M. J.; Baltazar, M. B.; Gomez, L. R.; Townsend, R.; Schoper, J. B. Maize pollen longevity and distance isolation requirements for effective pollen control. Crop Sci. 2001, 41, 1551-1557.

(4) Jemison, J. J.; Vayda, M. E. Cross pollination from genetically engineered corn: wind transport and seed source. AgBioForum 2001, 4, 87-92.

(5) Klein, E.; Lavigne, C.; Foueillassar, X.; Gouyon, P. H.; Larédo, C. Corn pollen dispersal: quasi-mechanistic models and field experiments. Ecological Monographs 2003, 73, $131-150$.

(6) Aylor, D. E.; Schultes, N. P.; Shields, E. J. An aerobiological framework for assessing cross-pollination in maize. Agric. For. Meteorol. 2003, 119, 111-129.

(7) Jarosz, N.; Loubet, B.; Huber, L. Modelling airborne concentration and deposition rate of maize pollen. Atmos. Environ. 2004, 38, 5555-5566. 
(8) Jarosz, N.; Loubet, B.; Durand, B.; McCartney, H. A.; Foueillassar, X.; Huber, L. Field measurements of airborne concentration and deposition of maize pollen. Agric. For. Meteorol. 2003, 119, 37-51.

(9) Raynor, G. S.; Ogden, E. C.; Hayes, J. V. Dispersion and deposition of corn pollen from experimental sources. Agron. J. 1972, 64, 420-427.

(10) Emberlin, J., A report on the dispersal of maize pollen. Soil association, Bristol, UK, 1999; available at http://www.soilassociation.org (accessed November 8, 2004).

(11) Feil, B.; Schmid, J. E. Dispersal of maize, wheat and rye pollen. A contribution to determining the necessary isolation distances for the cultivation of transgenic crops; Shaker Verlag: Aachen, Germany, 2002.

(12) Ogden, E. C.; Hayes, J. V.; Raynor, G. S. Diurnal patterns of pollen emission in Ambrosia, Phleum, Zea and Ricinus. Am. J. Bot. 1969, 56, 16-21.

(13) Hall, A. J.; Vilella, F.; Trapani, N.; Chimenti, C. The effect of water stress and genotype on the dynamics of pollen-shedding and silking in maize. Field Crops Res. 1982, 5, 349-363.

(14) Fonseca, A. E.; Westgate, M. E.; Doyle, R. T. Application of fluorescence microscopy and image analysis for quantifying dynamics of maize pollen shed. Crop Sci. 2002, 42, 2201-2206.

(15) McCartney, H. A.; Fitt, B. D. L.; Schmechel, D. Sampling bioaerosols in plant pathology. J. Aerosol Sci. 1997, 28, 349-364.

(16) Kaimal, J. C.; Finnigan, J. J. Atmospheric boundary layer flows, Their structure and measurement; Oxford University Press, 1994.

(17) McCartney, H. A.; Lacey, M. E. Wind dispersal of pollen from crops of oilseed rape (Brassica napus L.). J. Aerosol Sci. 1991, 22, 467-477.

(18) Raupach, M. R. Applying lagrangian fluid mechanics to infer scalar source distributions from concentration profiles in plant canopies. Agric. For. Meteorol. 1989, 47, 85-108.

(19) Flesch, T. K.; Wilson, J. D.; Yee, E. Backward-time lagrangian stochastic dispersion models and their application to estimate gaseous emissions. J. Appl. Meteorol. 1995, 34, 1320-1332.

(20) Aylor, D. E.; Flesch, T. K. Estimating spore release rates using a lagrangian stochastic simulation model. J. Appl. Meteorol. 2001, 40, 1196-1208.

(21) Wilson, J. D.; Flesch, T. K.; Harper, L. A. Micro-meteorological methods for estimating surface exchange with a disturbed windflow. Agric. For. Meteorol. 2001, 107, 207-225.

(22) Jarosz, N. Etude de la dispersion atmosphérique du pollen de maïs. Contribution à la maîtrise des risques de pollinisation croisée. PhD Thesis, Institut National Agronomique de Paris-Grignon, 2003; 225 pp.

(23) Aylor, D. E. Deposition gradients of ureniospores of Puccina recondita near a source. Ecology and Epidemiology 1987, 77, 1442-1448.

(24) Mahrt, L.; Moore, E.; Vickers, D.; Jensen, N. O. Dependence of turbulent and mesoscale velocity variances on scale and stability. J. Appl. Meteorol. 2001, 40, 628-641.

(25) Aylor, D. E. Settling speed of corn (Zea mays) pollen. J. Aerosol Sci. 2002, 33, 1601-1607.

(26) Di-Giovanni, F.; Kevan, P. G.; Nasr, M. E. The variability in settling velocities of some pollen and spores. Grana 1995, 34, 39-44.

(27) Seinfeld, J. H.; Pandis, S. N. Atmospheric chemistry and physics. From air pollution to climate change; Wiley-Interscience, 1998.

(28) Reynolds, A. M. Prediction of particle deposition on to rough surfaces. Agric. For. Meteorol. 2000, 104, 107-118. 
TABLE. Date, solar time, sampling line orientation and average micrometeorological conditions measured above and within the source plot during each experimental run. $R_{g}$ - global solar radiation; $R H$ - relative humidity; $T_{a}$ - air temperature; VPD - vapour pressure deficit of the air; $U$ - wind speed, Std WD - standard deviation of wind direction and $W D r$ - wind direction relative to sampling line direction. All measurements were made at a height of $2 \mathbf{m}$ at Grignon and $2.5 \mathrm{~m}$ at Sore except $U$ and $W D$ which were measured at $5 \mathrm{~m}$ and $4.3 \mathrm{~m}$ and $R_{\mathrm{g}}$ which was measured at $2.5 \mathrm{~m}$ and $5 \mathrm{~m}$ at $\mathrm{Grignon}$ and Sore, respectively. $u *$ the friction velocity, and $L$, the Monin-Obukhov length, were measured with the sonic anemometers at $4.5 \mathrm{~m}$ at Grignon and $6 \mathrm{~m}$ at Sore. Means and standard deviations are given. \% time is the time during which the wind was blowing from the maize field.

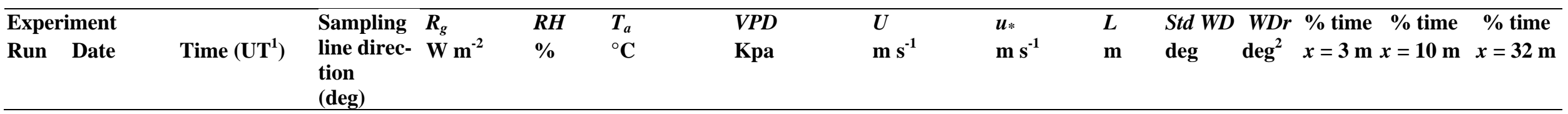

$$
\begin{aligned}
& 625 \\
& 557 \\
& 734 \\
& 861 \\
& 763 \\
& 667 \\
& 646 \\
& 544 \\
& 673 \\
& 685 \\
& 627 \\
& 591 \\
& 835 \\
& 728 \\
& 821 \\
& 749 \\
& 745 \\
& 526 \\
& 522 \\
& 659 \\
& 751 \\
&
\end{aligned}
$$

$\begin{array}{cccc}625 \pm 148 & 48 \pm 2 & 26.1 \pm 0.6 & 1.77 \pm 0.10 \\ 557 \pm 176 & 45 \pm 1 & 27.5 \pm 0.6 & 2.03 \pm 0.10 \\ 734 \pm 63 & 55 \pm 5 & 22.1 \pm 1.1 & 1.12 \pm 0.21 \\ 861 \pm 9 & 47 \pm 3 & 24.3 \pm 0.5 & 1.63 \pm 0.12 \\ 763 \pm 60 & 42 \pm 3 & 25.8 \pm 0.1 & 1.91 \pm 0.10 \\ 667 \pm 75 & 61 \pm 3 & 24.5 \pm 1.3 & 1.21 \pm 0.19 \\ 646 \pm 164 & 53 \pm 2 & 27.0 \pm 0.5 & 1.66 \pm 0.12 \\ 544 \pm 256 & 52 \pm 1 & 28.0 \pm 0.5 & 1.83 \pm 0.11 \\ & & & \\ 673 \pm 54 & 59 \pm 4 & 27.2 \pm 0.4 & 1.49 \pm 0.17 \\ 685 \pm 80 & 54 \pm 1 & 28.6 \pm 0.5 & 1.80 \pm 0.06 \\ 627 \pm 104 & 46 \pm 4 & 29.6 \pm 0.4 & 2.24 \pm 0.21 \\ 591 \pm 50 & 56 \pm 3 & 26.3 \pm 0.4 & 1.51 \pm 0.14 \\ 835 \pm 16 & 45 \pm 3 & 28.2 \pm 0.5 & 2.08 \pm 0.17 \\ 728 \pm 69 & 40 \pm 1 & 29.4 \pm 0.2 & 2.47 \pm 0.06 \\ 821 \pm 13 & 41 \pm 2 & 31.1 \pm 0.4 & 2.66 \pm 0.14 \\ 749 \pm 72 & 53 \pm 3 & 25.4 \pm 0.9 & 1.52 \pm 0.18 \\ 745 \pm 95 & 46 \pm 1 & 27.7 \pm 0.4 & 2.01 \pm 0.09 \\ & & & \\ 526 \pm 169 & 69 \pm 8 & 18.2 \pm 0.6 & 0.57 \pm 0.08 \\ 522 \pm 189 & 59 \pm 3 & 19.3 \pm 0.8 & 0.93 \pm 0.12 \\ 659 \pm 299 & 48 \pm 3 & 21.3 \pm 1.1 & 1.32 \pm 0.16 \\ 751 \pm 103 & 49 \pm 5 & 20.5 \pm 0.9 & 1.24 \pm 0.19\end{array}$

$\begin{array}{lll}2.5 \pm 0.6 & 0.27 \pm 0.10 & -11 \\ 2.4 \pm 0.4 & 0.29 \pm 0.13 & -15 \\ 2.4 \pm 0.2 & 0.23 \pm 0.10 & -4 \\ 2.8 \pm 0.3 & 0.31 \pm 0.09 & -9 \\ 2.7 \pm 0.3 & 0.31 \pm 0.10 & -8 \\ 2.1 \pm 0.4 & 0.21 \pm 0.08 & -4 \\ 2.3 \pm 0.3 & 0.28 \pm 0.08 & -8 \\ 2.2 \pm 0.3 & 0.28 \pm 0.09 & -11 \\ & & \\ 3.9 \pm 0.6 & 0.27 \pm 0.08 & -10 \\ 3.1 \pm 0.3 & 0.29 \pm 0.09 & -15 \\ 3.4 \pm 0.4 & 0.26 \pm 0.08 & -12 \\ 2.9 \pm 0.4 & 0.20 \pm 0.07 & -4 \\ 3.1 \pm 0.6 & 0.29 \pm 0.10 & -9 \\ 3.6 \pm 0.5 & 0.31 \pm 0.08 & -13 \\ 1.9 \pm 0.6 & 0.26 \pm 0.11 & -13 \\ 4.7 \pm 0.3 & 0.36 \pm 0.08 & -18 \\ 4.1 \pm 0.4 & 0.34 \pm 0.12 & -18 \\ & & \\ 7.1 \pm 0.7 & 0.71 \pm 0.09 & -367 \\ 5.7 \pm 0.5 & 0.56 \pm 0.06 & -133 \\ 7.2 \pm 0.7 & 0.68 \pm 0.09 & -148 \\ 2.6 \pm 0.5 & 0.31 \pm 0.10 & -17\end{array}$

$\begin{array}{ccccc}15 & -1 & 100 \% & 100 \% & 77 \% \\ 35 & -39 & 84 \% & 56 \% & 22 \% \\ 31 & 52 & 75 \% & 42 \% & 12 \% \\ 35 & 33 & 87 \% & 62 \% & 25 \% \\ 14 & 41 & 99 \% & 62 \% & 4 \% \\ 29 & 96 & 22 \% & 4 \% & 0 \% \\ 29 & 87 & 32 \% & 7 \% & 1 \% \\ 24 & 85 & 31 \% & 5 \% & 0 \% \\ & & & & \\ 19 & 90 & 19 \% & 1 \% & 0 \% \\ 28 & 79 & 41 \% & 11 \% & 1 \% \\ 29 & 81 & 40 \% & 11 \% & 2 \% \\ 26 & 100 & 14 \% & 1 \% & 0 \% \\ 30 & 111 & 11 \% & 2 \% & 0 \% \\ 28 & 100 & 16 \% & 2 \% & 0 \% \\ \mathrm{nd}^{3} & -17 & \mathrm{nd} & \mathrm{nd} & \\ 16 & 128 & 0 \% & 0 \% & \mathrm{nd} \\ 20 & 127 & 0 \% & 0 \% & 0 \% \\ & & & & \\ 15 & -14 & 100 \% & 98 \% & 57 \% \\ 20 & -10 & 100 \% & 95 \% & 55 \% \\ 22 & -15 & 100 \% & 91 \% & 47 \% \\ 31 & -5 & 98 \% & 85 \% & 42 \%\end{array}$

$\begin{array}{lll}7.2 \pm 0.7 & 0.68 \pm 0.09 & -148 \\ 0.5 & 0.31 \pm 0.10 & -17\end{array}$

\section{Supporting information appendix}

\section{1}

$1^{\text {st }}$ flowering date

$\mathrm{S}_{0} 122$ July

$\mathrm{S}_{0} 22$ July

$\mathrm{S}_{0} 324$ July

$\mathrm{S}_{0} 4 \quad 24$ July

$\mathrm{S}_{0} 524$ July

$\mathrm{S}_{0} 6 \quad 25$ July

$\mathrm{S}_{0} 725$ July

$\mathrm{S}_{0} 825$ July

$\mathrm{S}_{1} 9 \quad 28$ July

$\mathrm{S}_{1} 10 \quad 28$ July

$\mathrm{S}_{1} 11 \quad 28$ July

$\mathrm{S}_{1} 12 \quad 29$ July

$\mathrm{S}_{1} 13 \quad 29$ July

$\mathrm{S}_{1} 14 \quad 29$ July

$\mathrm{S}_{1} 1530$ July

$\mathrm{S}_{1} 161$ August

$\mathrm{S}_{1} 171$ August

$2^{\text {nd }}$ flowering date

$\mathrm{S}_{2} 199$ August

$\mathrm{S}_{2} 209$ August $12: 10-14: 20$

$\mathrm{S}_{2} 21$ 11 August 9:25-12:25

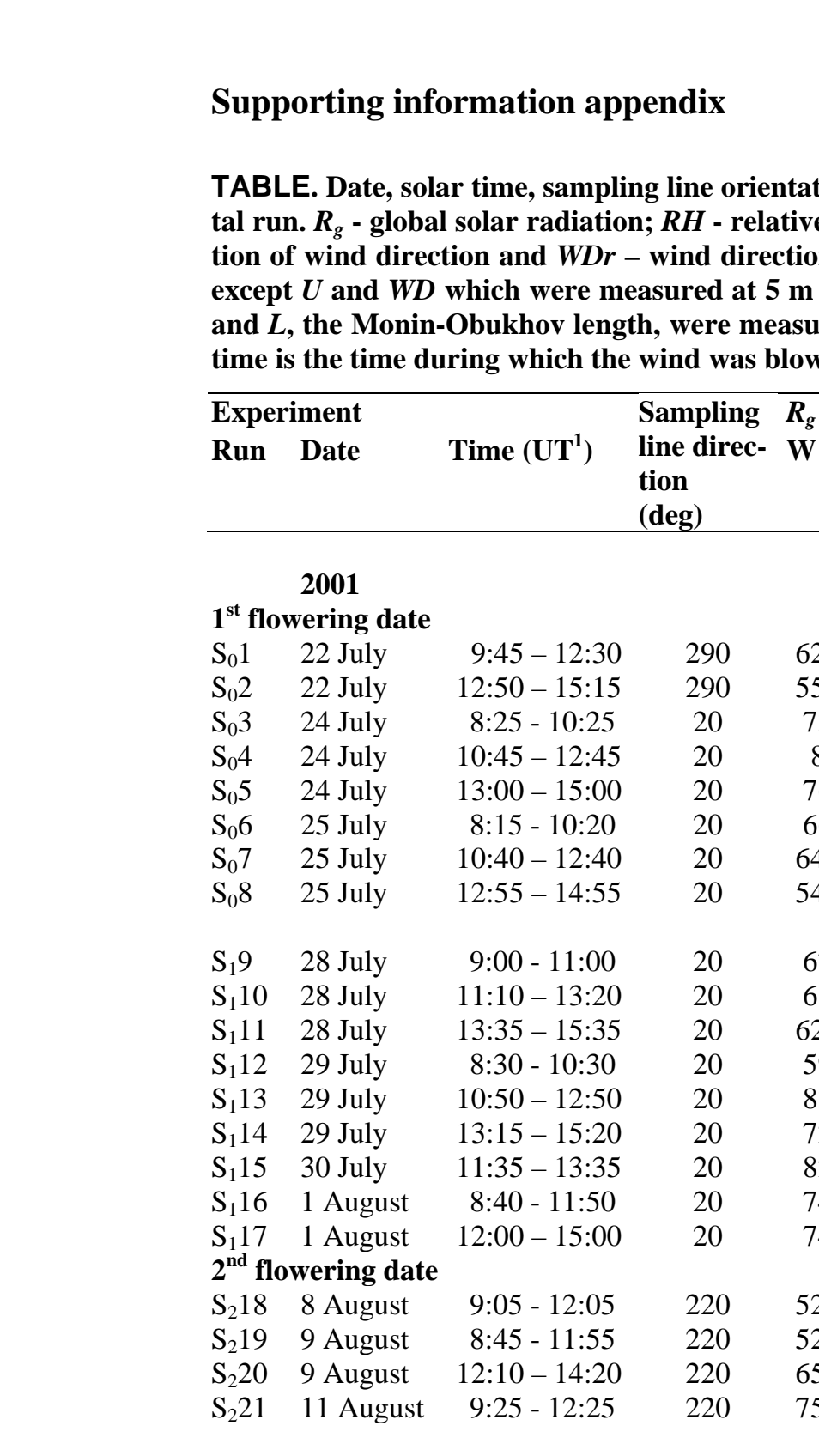


Supporting information appendix

TABLE continued.

\begin{tabular}{|c|c|c|c|c|c|c|c|c|c|c|c|c|c|c|c|}
\hline $\begin{array}{l}\text { Exper } \\
\text { Run }\end{array}$ & $\begin{array}{l}\text { iment } \\
\text { Date }\end{array}$ & Time (UT $\left.{ }^{\mathbf{1}}\right)$ & $\begin{array}{l}\text { Sampling } \\
\text { line direc- } \\
\text { tion } \\
(\mathrm{deg})\end{array}$ & $\begin{array}{l}R_{g} \\
\mathbf{W} \mathbf{m}^{-2}\end{array}$ & $\begin{array}{l}R H \\
\%\end{array}$ & $\begin{array}{l}T_{a} \\
{ }^{\circ} \mathbf{C}\end{array}$ & $\begin{array}{l}V P D \\
\mathrm{kPa}\end{array}$ & $\begin{array}{l}U \\
\mathrm{~m} \mathrm{~s}^{-1}\end{array}$ & $\begin{array}{l}U_{*} \\
\mathbf{m ~ s}^{-1}\end{array}$ & $\begin{array}{l}L \\
\mathbf{m}\end{array}$ & $\begin{array}{l}\text { Std WD } \\
\text { deg }\end{array}$ & $\begin{array}{l}\text { WDr } \\
\operatorname{deg}^{2}\end{array}$ & $\begin{array}{l}\text { \% time } \\
x=3 \mathrm{~m}\end{array}$ & $\begin{array}{c}\% \text { time } \\
x=10 \mathrm{~m}\end{array}$ & $\begin{array}{c}\text { \% time } \\
x=32 \mathrm{~m}\end{array}$ \\
\hline $\mathrm{S}_{2} 22$ & 11 August & $12: 45-14: 45$ & 220 & $753 \pm 57$ & $41 \pm 1$ & $22.6 \pm 0.5$ & $1.63 \pm 0.07$ & $2.6 \pm 0.4$ & $0.31 \pm 0.14$ & -13 & 37 & -34 & $86 \%$ & $60 \%$ & $25 \%$ \\
\hline $\mathrm{S}_{2} 23$ & 12 August & $9: 45-11: 45$ & 220 & $773 \pm 38$ & $43 \pm 2$ & $23.7 \pm 0.7$ & $1.67 \pm 0.12$ & $4.2 \pm 0.4$ & $0.41 \pm 0.08$ & -40 & 23 & 4 & $100 \%$ & $94 \%$ & $53 \%$ \\
\hline $\mathrm{S}_{2} 24$ & 12 August & $12: 05-14: 10$ & 220 & $767 \pm 82$ & $40 \pm 1$ & $26.0 \pm 0.7$ & $2.03 \pm 0.12$ & $3.9 \pm 0.5$ & $0.38 \pm 0.09$ & -30 & 31 & 13 & $97 \%$ & $82 \%$ & $40 \%$ \\
\hline $\mathrm{S}_{2} 25$ & 12 August & $14: 30-16: 30$ & 220 & $498 \pm 86$ & $38 \pm 1$ & $26.3 \pm 0.3$ & $2.12 \pm 0.03$ & $4.2 \pm 0.3$ & $0.38 \pm 0.05$ & -65 & 29 & -2 & $99 \%$ & $87 \%$ & $44 \%$ \\
\hline $\mathrm{S}_{2} 26$ & 13 August & $8: 45-10: 45$ & 220 & $678 \pm 58$ & $61 \pm 4$ & $22.9 \pm 1.3$ & $1.09 \pm 0.20$ & $3.0 \pm 0.7$ & $0.32 \pm 0.09$ & -20 & 69 & 98 & $35 \%$ & $20 \%$ & $7 \%$ \\
\hline $\mathrm{S}_{2} 27$ & 13 August & $11: 00-13: 00$ & 220 & $798 \pm 6$ & $50 \pm 4$ & $26.8 \pm 0.9$ & $1.77 \pm 0.23$ & $3.3 \pm 0.7$ & $0.38 \pm 0.12$ & -35 & 41 & -2 & $93 \%$ & $73 \%$ & $33 \%$ \\
\hline $\mathrm{S}_{2} 28$ & 13 August & $13: 10-15: 10$ & 220 & $688 \pm 58$ & $42 \pm 3$ & $28.5 \pm 0.4$ & $2.26 \pm 0.13$ & $3.2 \pm 0.4$ & $0.38 \pm 0.07$ & -39 & 40 & -14 & $91 \%$ & $71 \%$ & $32 \%$ \\
\hline $\mathrm{S}_{2} 29$ & 14 August & $9: 20$ - 11:35 & 160 & $735 \pm 52$ & $47 \pm 3$ & $28.9 \pm 0.7$ & $2.12 \pm 0.19$ & $2.8 \pm 0.4$ & $0.31 \pm 0.09$ & -20 & 38 & 112 & $15 \%$ & $4 \%$ & $1 \%$ \\
\hline $\mathrm{S}_{2} 30$ & 14 August & $11: 50-14: 05$ & 160 & $778 \pm 26$ & $41 \pm 2$ & $30.5 \pm 0.5$ & $2.58 \pm 0.16$ & $3.5 \pm 0.5$ & $0.39 \pm 0.08$ & -43 & 36 & 116 & $11 \%$ & $2 \%$ & $0 \%$ \\
\hline$S_{2} 31$ & 15 August & $8: 50$ - 12:05 & 200 & $683 \pm 130$ & $52 \pm 8$ & $29.2 \pm 2.0$ & $2.00 \pm 0.52$ & $4.9 \pm 0.5$ & $0.48 \pm 0.08$ & -70 & 30 & 34 & $90 \%$ & $64 \%$ & $25 \%$ \\
\hline $\mathrm{S}_{2} 32$ & 15 August & $12: 15$ - 15:25 & 200 & $691 \pm 94$ & $40 \pm 2$ & $32.3 \pm 0.3$ & $2.90 \pm 0.15$ & $6.1 \pm 0.9$ & $0.57 \pm 0.08$ & -131 & 31 & 24 & $94 \%$ & $73 \%$ & $32 \%$ \\
\hline & 2002 & & & & & & & & & & & & $x=20 \mathrm{~m}$ & $x=100 \mathrm{~m}$ & $x=200 \mathrm{~m}$ \\
\hline A1 & 16 July & $7: 15-17: 00$ & 310 & $429 \pm 148$ & $65 \pm 9$ & $23.0 \pm 1.6$ & $1.00 \pm 0.30$ & $2.3 \pm 0.8$ & $0.38 \pm 0.12$ & -75 & 38 & -12 & $97 \%$ & $91 \%$ & $58 \%$ \\
\hline A2 & 17 July & $7: 00$ - 17:00 & 310 & $549 \pm 197$ & $71 \pm 11$ & $23.2 \pm 1.8$ & $0.86 \pm 0.39$ & $2.2 \pm 0.6$ & $0.32 \pm 0.11$ & -26 & 45 & -16 & $92 \%$ & $84 \%$ & $49 \%$ \\
\hline A3 & 18 July & $7: 20-16: 45$ & 310 & $722 \pm 159$ & $52 \pm 15$ & $27.0 \pm 3.1$ & $1.81 \pm 0.72$ & $1.6 \pm 0.5$ & $0.12 \pm 0.17$ & -1 & 126 & 112 & $36 \%$ & $29 \%$ & $14 \%$ \\
\hline A4 & 20 July & $7: 10$ - 17:20 & 310 & $562 \pm 220$ & $65 \pm 14$ & $28.0 \pm 4.6$ & $1.50 \pm 0.79$ & $0.3 \pm 0.1$ & $0.15 \pm 0.11$ & -2 & 85 & -18 & $67 \%$ & $56 \%$ & $29 \%$ \\
\hline A5 & 21 July & $7: 15$ - 18:30 & 310 & $611 \pm 226$ & $57 \pm 11$ & $27.0 \pm 2.2$ & $1.59 \pm 0.51$ & $0.9 \pm 0.9$ & $0.20 \pm 0.19$ & -1 & 77 & -33 & $69 \%$ & $58 \%$ & $30 \%$ \\
\hline A6 & 22 July & $7: 30-17: 45$ & 310 & $571 \pm 271$ & $57 \pm 9$ & $23.1 \pm 1.6$ & $1.24 \pm 0.32$ & $1.8 \pm 0.6$ & $0.27 \pm 0.14$ & -5 & 77 & 86 & $48 \%$ & $39 \%$ & $18 \%$ \\
\hline A7 & 23 July & $7: 25$ - 17:20 & 310 & $683 \pm 175$ & $48 \pm 13$ & $25.6 \pm 1.6$ & $1.76 \pm 0.53$ & $2.3 \pm 1.3$ & $0.41 \pm 0.22$ & -30 & 48 & -9 & $92 \%$ & $84 \%$ & $49 \%$ \\
\hline
\end{tabular}

1. Universal Time $=$ Local Time $-2: 00$

2. The wind direction is given relative to the direction of the sampling masts.

3. nd means not determined, due to a non Gaussian distribution. 